\title{
Dopamine regulates pancreatic glucagon and insulin secretion via adrenergic and dopaminergic receptors
}

Despoina Aslanoglou', Suzanne Bertera $\mathbb{C}^{2}$, Marta Sánchez-Soto ${ }^{3}$, R. Benjamin Free $\mathbb{C}^{3}$, Jeongkyung Lee ${ }^{4}$, Wei Zong ${ }^{5}$, Xiangning Xue ${ }^{5}$, Shristi Shrestha ${ }^{6}$, Marcela Brissova ${ }^{6}$, Ryan W. Logan ${ }^{1,7}$, Claes B. Wollheim ${ }^{8}$, Massimo Trucco ${ }^{2,9,10}$, Vijay K. Yechoor ${ }^{4}$, David R. Sibley $\mathbb{B}^{3}$, Rita Bottino ${ }^{2,9,10}$ and Zachary Freyberg (10) ${ }^{1,11}$

\begin{abstract}
Dopamine (DA) and norepinephrine (NE) are catecholamines primarily studied in the central nervous system that also act in the pancreas as peripheral regulators of metabolism. Pancreatic catecholamine signaling has also been increasingly implicated as a mechanism responsible for the metabolic disturbances produced by antipsychotic drugs (APDs). Critically, however, the mechanisms by which catecholamines modulate pancreatic hormone release are not completely understood. We show that human and mouse pancreatic $a$ - and $\beta$-cells express the catecholamine biosynthetic and signaling machinery, and that a-cells synthesize DA de novo. This locally-produced pancreatic DA signals via both $\alpha$ - and $\beta$-cell adrenergic and dopaminergic receptors with different affinities to regulate glucagon and insulin release. Significantly, we show DA functions as a biased agonist at $a_{2 A}$-adrenergic receptors, preferentially signaling via the canonical G protein-mediated pathway. Our findings highlight the interplay between DA and NE signaling as a novel form of regulation to modulate pancreatic hormone release. Lastly, pharmacological blockade of DA $D_{2}$-like receptors in human islets with APDs significantly raises insulin and glucagon release. This offers a new mechanism where APDs act directly on islet $\alpha$ - and $\beta$-cell targets to produce metabolic disturbances.
\end{abstract}

\section{Introduction}

Antipsychotic drugs (APDs) are widely used worldwide to treat highly prevalent psychiatric illnesses including schizophrenia, bipolar disorder, and major depressive disorder ${ }^{1,2}$. However, these drugs also cause profound metabolic dysfunction including dysglycemia and systemic insulin resistance that increase the risk of type 2 diabetes (T2D) ${ }^{3}$. Significantly, all APDs cause metabolic side effects to differing degrees, and current treatments to reduce these metabolic symptoms have only limited efficacy ${ }^{4}$. The single unifying property of APDs is their

\footnotetext{
Correspondence: Zachary Freyberg (freyberg@pitt.edu)

${ }^{1}$ Translational Neuroscience Program, Department of Psychiatry, University of Pittsburgh, Pittsburgh, PA, USA

${ }^{2}$ Institute of Cellular Therapeutics, Allegheny Health Network Research

Institute, Allegheny Health Network, Pittsburgh, PA, USA

Full list of author information is available at the end of the article
}

blockade of dopamine $\mathrm{D}_{2}$-like receptors, including $\mathrm{D}_{2}$ (D2R) and $\mathrm{D}_{3}(\mathrm{D} 3 \mathrm{R})$ receptors. This suggests key roles for D2R and D3R not only in promoting APDs' therapeutic actions, but also in causing their metabolic side effects.

We and our colleagues found that D2R and D3R are expressed not only in the central nervous system (CNS) but also in pancreatic $\beta$-cells, and that these receptors are important negative regulators of insulin secretion ${ }^{5-9}$. Direct stimulation of $\beta$-cell D2R and D3R with dopamine (DA) or D2R/D3R agonists inhibits glucose-stimulated insulin secretion (GSIS) in both human and mouse pancreatic islets $^{6-8,10}$, suggesting that $\beta$-cell D2R/D3R signaling is an important regulator of GSIS $5,6,8,9$. Indeed, in vivo human and rodent studies demonstrated that treatment with the DA precursor L-DOPA causes hyperglycemia due to decreased GSIS $^{11-14}$. Conversely, we previously showed that the APD blockade of $\beta$-cell

\section{(c) The Author(s) 2021}

(c) (i) Open Access This article is licensed under a Creative Commons Attribution 4.0 International License, which permits use, sharing, adaptation, distribution and reproduction in any medium or format, as long as you give appropriate credit to the original author(s) and the source, provide a link to the Creative Commons license, and indicate if changes were made. The images or other third party material in this article are included in the article's Creative Commons license, unless indicated otherwise in a credit line to the material. If material is not included in the article's Creative Commons license and your intended use is not permitted by statutory regulation or exceeds the permitted use, you will need to obtain permission directly from the copyright holder. To view a copy of this license, visit http://creativecommons.org/licenses/by/4.0/. 
D2R/D3R enhances GSIS ${ }^{6}$. As in T2D, APD-induced increases in circulating insulin are hypothesized to desensitize insulin-sensitive peripheral targets (e.g., liver, skeletal muscle, adipose tissue) over time, resulting in insulin resistance and weight gain ${ }^{3,4,15}$.

Despite a still-limited understanding of dopaminergic regulation of $\beta$-cells, even less is known about glucagonsecreting pancreatic $\alpha$-cells ${ }^{16}$. Like insulin, glucagon is a key regulator of glucose homeostasis, raising blood glucose during decreased glucose availability via stimulation of hepatic glucose production ${ }^{17,18}$. Notably, inappropriately elevated glucagon levels are a characteristic feature of APD treatment in humans and rodents ${ }^{16,19-21}$. Since rodent and human $\alpha$-cells express DA $D_{2}$-like receptors $^{22,23}$, APDs may also directly target $\alpha$-cell D2R/D3R to raise glucagon and drive hyperglycemia, further contributing to insulin resistance. However, little is known about the roles of these DA receptors in regulating $\alpha$-cell function. Thus, elucidating D2R/D3R signaling in $\alpha$-cells may shed important new light on dopaminergic regulation of glucagon release as well as offer new mechanisms and therapeutic targets for APD-induced metabolic disturbances.

Just as fundamentally, the precise sources of DA acting on $\alpha$ - and $\beta$-cell dopaminergic receptors are still poorly understood. Earlier work primarily focused on islet sources of the related catecholamine, norepinephrine $(\mathrm{NE})^{6,7,9,24}$. Sympathetic nervous innervation was long considered a primary source of NE acting on the endocrine pancreas ${ }^{25,26}$. However, the degree of islet innervation is unclear, particularly in humans, and recent evidence suggests only sparse sympathetic innervation of human islets ${ }^{26-32}$. Islets also lack direct dopaminergic innervation $^{32,33}$. Together, these data point to the importance of locally-produced, non-neuronal sources of both NE and DA for catecholamine signaling in $\alpha$ - and $\beta$-cells ${ }^{6,7,32,33}$. Indeed, mouse and human islets produce DA independently of sympathetic innervation, particularly in response to uptake of precursors like L-3,4-dihydroxyphenylalanine (L-DOPA $)^{6,7,9,30,33-36}$. We and others previously showed that human and rodent $\beta$-cells express critical components of the catecholamine biosynthetic machinery including tyrosine hydroxylase $(\mathrm{TH})$, Dopa decarboxylase (DDC), and the vesicular monoamine transporter (VMAT), allowing these cells to produce, package and secrete $\mathrm{DA}^{6,7,9,37-39}$. Nevertheless, it remains unclear whether additional islet cell types including $\alpha$ cells are also responsible for islet catecholamine production.

Here, we show that, like $\beta$-cells, mouse and human $\alpha$ cells express the complete catecholamine biosynthetic, transport, and catabolic machinery. Consequently, $\alpha$-cells synthesize both DA and NE de novo, though preferentially produce DA in response to uptake of precursor
L-DOPA. Significantly, we provide evidence that DA modulates both glucagon and insulin release by signaling directly via $\alpha$ - and $\beta$-cell adrenergic receptors in human and mouse islets. Furthermore, at $\alpha_{2 \mathrm{~A}}$-adrenergic receptors, DA functions as a biased ligand, preferentially signaling via $G \alpha$ protein recruitment but not through $\beta$-arrestin2, providing a new mechanism for DA's intracellular signaling at these receptors. Lastly, we demonstrate that pharmacological $\mathrm{D}_{2}$-like receptor blockade by APDs significantly elevates glucagon as well as insulin secretion in human pancreatic islets. This suggests that APDs act directly on islet $\alpha$-cells, in addition to $\beta$-cells, to disrupt the $\mathrm{D}_{2}$-like receptor signaling responsible for regulating islet hormone secretion. Thus, such APDinduced disruptions may drive the development of disturbed glucose homeostasis commonly found in treated patients ${ }^{16,40,41}$. Together, our findings provide new mechanisms for how DA and NE signaling regulates insulin and glucagon release. This work also offers a new context for APDs' actions in the periphery that may explain how APDs produce metabolic dysfunction.

\section{Materials and methods Compounds}

Compounds used in this study were purchased from Sigma-Aldrich (St. Louis, MO) unless indicated otherwise: HEPES, sodium pyruvate (Gibco/ThermoFisher Scientific, Pittsburgh, PA), penicillin/streptomycin, 2-mercaptoethanol, D-glucose, bovine serum albumin (BSA; Merck Millipore, Darmstadt, Germany), EDTA, ascorbic acid, $S$ (-)-propranolol, $R$-(-)-deprenyl hydrochloride, pargyline hydrochloride, clorgyline hydrochloride, yohimbine (Tocris, Bristol, United Kingdom), haloperidol, clozapine, olanzapine (Tocris), and $\left[{ }^{3} \mathrm{H}\right] \mathrm{RX} 821002$ (Perkin Elmer, Billerica, MA).

\section{Cell culture}

aTC1 clone 6 ( $\alpha \mathrm{TC} 1-6)$ cells [American Type Tissue Culture Collection (ATCC), \#CRL-2934, Manassas, VA] were cultured in DMEM medium (Gibco) supplemented with $10 \%$ fetal bovine serum (FBS), $100 \mathrm{U} / \mathrm{mL}$ penicillin/ streptomycin, $15 \mathrm{mM}$ HEPES, $0.1 \mathrm{mM}$ non-essential amino acids, $0.02 \%$ BSA, $15 \mathrm{mg} / \mathrm{L}$ sodium bicarbonate, $2 \mathrm{mg} / \mathrm{L}$ glucose. INS-1E cells (gift of Dr. Pierre Maechler, Université de Genève) and all clonally-derived cell lines were cultured as described previously $y^{7,10,42}$. Briefly, INS1E cells were maintained in RPMI 1640 medium (Gibco) supplemented with $5 \%(\mathrm{v} / \mathrm{v})$ heat-inactivated fetal bovine serum, $2 \mathrm{mM}$ L-glutamine, $10 \mathrm{mM}$ HEPES, $1 \mathrm{mM}$ sodium pyruvate, $100 \mathrm{U} / \mathrm{mL}$ penicillin/streptomycin and $50 \mu \mathrm{M} 2$ mercaptoethanol. HEK-293 cells (ATCC, \#CRL-1573) were cultured in DMEM medium (Gibco) supplemented with $10 \% \mathrm{FBS}$ and $100 \mathrm{U} / \mathrm{mL}$ penicillin/streptomycin. Cell lines were maintained in a humidified $37^{\circ} \mathrm{C}$ incubator 
with $5 \% \mathrm{CO}_{2}$. All cell lines tested negative for mycoplasma contamination.

\section{Generation of $a_{2 A}$-adrenergic receptor knockout cell line}

We employed a CRISPR-Cas9-mediated approach to delete endogenous $\alpha_{2 \mathrm{~A}}$-adrenergic receptor expression in INS-1E cells. Since INS-1E cells are rat-derived, we used the mRNA sequence encoding rat $\alpha_{2 \mathrm{~A}}$-adrenergic receptor as a template to generate guide RNA (gRNA) to disrupt the promoter region of the Adra2a gene (gRNA sequence: 5'-GCAGCCGGATGCCGGCAATA-3', positions 57-76). We then generated a construct containing the Adra2a gRNA sequence along with cDNA sequences encoding Cas9 and GFP (pENTR-Adra2a-sgRNA-Cas9GFP). $1-5 \mu \mathrm{g}$ of the construct was subsequently transfected into low-passage INS-1E cells using Lipofectamine 3000 (ThermoFisher Scientific) according to manufacturer instructions. $24-48 \mathrm{~h}$ post-transfection, the transfected cells were identified and collected by fluorescence-activated cell sorting based on GFP fluorescence using a BD FACSAria II sorter (BD Biosciences, San Jose, CA) equipped with a GFP filter $(530 / 30 \mathrm{~nm})$. Single cells were sorted into 96-well plates in complete RPMI 1640 medium and allowed to recover for $72 \mathrm{~h}$ before the addition of fresh media. Upon recovery and expansion, a number of clonal cell lines were generated and initially screened for complete $\alpha_{2}$-adrenergic receptor knockout by qPCR followed by additional functional validation via insulin secretion and radioligand binding assays.

\section{Animal husbandry}

Animals were housed and handled in accordance with appropriate NIH guidelines through the University of Pittsburgh Institutional Animal Care and Use Committee (Protocol \# 19075490), which approved the study. We abided by all appropriate animal care guidelines including ARRIVE guidelines for reporting animal research. Mice were housed in cages with a 12:12 light:dark cycle and had access to food and water ad lib at all times unless indicated otherwise. Every effort was made to ameliorate animal suffering.

\section{Human subjects}

Pancreata and islets from non-diabetic adult donors were obtained via a partnership with CORE (Center for Organ Recovery and Education). Donor demographic information is summarized in Supplementary Table S1. The University of Pittsburgh Institutional Review Board declared studies on de-identified human pancreatic specimens do not qualify as human subject research.

\section{Pancreatic islet preparation}

For mouse pancreatic islet preparations, islets were obtained from 8 to 10 -week-old wild-type BALB/c mice.
Islets were freshly isolated via collagenase digestion of pancreata as described previously ${ }^{43}$. Human pancreatic islets were isolated via collagenase digestion and purified from four non-diabetic human donors (Supplementary Table S1) as described previously ${ }^{44}$. Following isolation and purification, human or mouse islets were plated at a density of 15 islets per well into 24-well tissue culturetreated plates. Islets were allowed to recover overnight, free-floating in RPMI 1640 complete media, supplemented with $10 \%$ FBS. The islets were used immediately after overnight recovery for hormone secretion assays.

\section{Catecholamine secretion and measurement Catecholamine secretion assay}

Cell-based catecholamine secretion assays were conducted as reported earlier ${ }^{7}$. Briefly, $\alpha \mathrm{TC} 1-6$ cells were seeded into 24-well plates at an initial seeding density of $5 \times 10^{5}$ cells/well in complete DMEM medium. On the experimental day, cells were washed twice and placed into KRB buffer $(132.2 \mathrm{mM} \mathrm{NaCl}, 3.6 \mathrm{mM} \mathrm{KCl}, 5 \mathrm{mM}$ $\mathrm{NaHCO}_{3}, 0.5 \mathrm{mM} \mathrm{NaH} \mathrm{PO}_{4}, 0.5 \mathrm{mM} \mathrm{MgCl}, 1.5 \mathrm{mM}$ $\mathrm{CaCl}_{2}$ and $0.001 \mathrm{~g} / \mathrm{mL}$ BSA, $\mathrm{pH}$ 7.4) supplemented with $25 \mathrm{mM}$ glucose $\left(1 \mathrm{~h}, 37^{\circ} \mathrm{C}, 5 \% \mathrm{CO}_{2}\right)$. Some samples were also supplemented with $10 \mu \mathrm{M}$ L-DOPA to boost cell catecholamine production in the presence or absence of a monoamine oxidase inhibitor cocktail $(10 \mu \mathrm{M}$ : deprenyl, pargyline, clorgyline). At assay conclusion, supernatants were immediately collected from each sample and placed directly into cold HeGa solution (0.1 M glacial acetic acid, $0.1 \mathrm{mM}$ EDTA, and $0.12 \%$ oxidized L-glutathione, $\mathrm{pH}$ 3.7) on ice to protect catecholamine content from oxidation. Cell lysates were prepared by placing cells in lysis buffer containing 25\% Triton X-100 with shaking for $1 \mathrm{~h}$. Lysates were collected and centrifuged at 17,000 rpm for $5 \mathrm{~min}$ at $4{ }^{\circ} \mathrm{C}$ to pellet cell debris and then added into HEGA buffer for High-Performance Liquid Chromatography (HPLC) analysis.

\section{Measurement of catecholamines and metabolites by HPLC}

Assay samples were filtered $(0.20 \mu \mathrm{m}$ filter; ThermoFisher Scientific) and analyzed via HPLC with electrochemical detection as previously reported ${ }^{7}$. Briefly, samples were separated on a C18 reverse-phase column (Hypersil ODS C18 column, ThermoFisher Scientific) with MD-TM mobile phase (ThermoFisher Scientific). Catecholamines DA and NE, precursor L-DOPA as well as catecholamine metabolites DOPAC and HVA were detected on a ThermoScientific Dionex UltiMate 3000 ECD-3000RS Electrochemical Detector (ThermoFisher Scientific) at $300 \mathrm{mV}$ oxidation potential. The Chromeleon Chromatography Data System software package (ThermoFisher Scientific, version 7) quantified catecholamine (DA, NE), L-DOPA and metabolite (DOPAC, HVA) content present in each sample from the respective 
areas under the HPLC peaks based on defined calibration curves.

\section{Hormone secretion assays and measurement Islet secretion assay}

Measurements of hormone secretion were performed using static incubation of pancreatic islets. Following islet isolation and recovery, human or mouse islets were transitioned from complete RPMI 1640 medium (containing $11 \mathrm{mM}$ glucose) to complete RPMI 1640 media supplemented with $25 \mathrm{mM}$ glucose. The increased glucose (25 mM) was used to inhibit $\alpha$-cell glucagon secretion to diminish glucagon levels to basal levels to improve the dynamic range of the assay and thus effectively unmask the role of ligand-mediated glucagon secretion as described earlier ${ }^{45}$. Islets were then transferred to a 24-well plate containing KRB buffer also supplemented with $25 \mathrm{mM}$ glucose. Drug treatments were added in KRB (25 mM glucose) $\left(1 \mathrm{hr}, 37^{\circ} \mathrm{C}, 5 \% \mathrm{CO}_{2}\right)$. After treatment, KRB was supplemented with a protease inhibitor cocktail (1 tablet/10 mL KRB; Roche Diagnostics, Mannheim, Germany) to prevent glucagon degradation. Supernatants were collected and placed on ice to further prevent glucagon degradation and precipitation. Undiluted supernatants and 1:2 dilutions were used for the glucagon detection assay, while 1:10 dilutions were used for insulin measurement; all dilutions were in KRB.

\section{Glucose-stimulated insulin secretion (GSIS) in INS-1E cells}

Insulin secretion assays in INS-1E cells were conducted as described earlier ${ }^{7,42}$. Briefly, cells were seeded into 24well plates (pre-coated with poly-L-Lysine) in RPMI 1640 complete media at $5 \times 10^{5}$ cells/well and cells were cultured overnight $\left(37^{\circ} \mathrm{C}, 5 \% \mathrm{CO}_{2}\right)$. Insulin secretion was carried out $48 \mathrm{~h}$ after seeding the cells. On an experimental day, cells were first glucose-starved in KRB (0 mM glucose) for $1 \mathrm{~h}\left(37^{\circ} \mathrm{C}, 5 \% \mathrm{CO}_{2}\right)$, followed by glucose stimulation with KRB supplemented with $20 \mathrm{mM}$ glucose in the presence or absence of drugs for $90 \mathrm{~min}\left(37^{\circ} \mathrm{C}, 5 \%\right.$ $\mathrm{CO}_{2}$ ). The supernatants were collected and diluted 1:10 in $\mathrm{KRB}$ for the insulin detection assay.

\section{Hormone detection assays}

For glucagon detection, we used a commercially available glucagon detection kit (Cisbio Bioassays, Bedford, MA). The assay is based on homogeneous time-resolved fluorescence resonance energy transfer (HTRF) technology. Standard curve and assay samples $(10 \mu \mathrm{L} /$ well $)$ were plated into a 384-well white, low-volume, round-bottom plate (Corning, Corning, NY). The two anti-glucagon antibodies were mixed in a 1:1 donor (cryptate)/acceptor (d2) ratio in the glucagon assay detection buffer (Cisbio Bioassays) and $10 \mu \mathrm{L}$ of this glucagon antibody mix was added to each well. Secreted insulin was similarly detected and measured by an HTRF approach using the insulin high range detection kit (Cisbio Bioassays) as described previously ${ }^{42}$. The two anti-insulin antibodies were mixed in a 1:2 donor (cryptate)/acceptor (XL665) ratio in the insulin assay detection buffer (Cisbio Bioassays) and $15 \mu \mathrm{L}$ of the insulin antibody mix was added per well. For both glucagon and insulin HTRF assays, the incubation time was $2 \mathrm{~h}$ at room temperature. Plates were read using a PheraStar FSX equipped with an HTRF optic module (337 $665620 \mathrm{~mm}$ ) (BMG Labtech, Ortenberg, Germany). Integration start was set at 60 microseconds and the integration time was 400 microseconds with 200 flashes/ well. The insulin and glucagon concentrations of the assay wells were derived via extrapolation of ratiometric fluorescence readings $(665 \mathrm{~nm} / 620 \mathrm{~nm})$ to a second-order quadratic polynomial curve. The raw data were obtained in $\mathrm{ng} / \mathrm{mL}$ insulin secreted and $\mathrm{pg} / \mathrm{mL}$ glucagon secreted. Dose-response curves were fit via non-linear regression of Log[ligand] versus normalized \% glucagon or insulin secretion. Investigators were blinded to the identity of samples during the initial analysis.

\section{Quantitative real-time PCR}

Total RNA from INS-1E cells and the INS-1E-derived $\alpha_{2 \mathrm{~A}}$-adrenergic receptor knockout cell line were isolated using the RNeasy Plus micro Kit (Qiagen, Valencia, CA). The isolated mRNA was reverse transcribed via the Superscript III First-Strand Synthesis System (ThermoFisher Scientific) according to manufacturers' instructions. For quantitative real-time PCR (qPCR) assays, expression levels of rat $\alpha_{2 \mathrm{~A}}$-adrenergic receptor (Adra2a) were detected using the QuantiTect SYBR Green PCR Kit (Qiagen) and SYBR Select Master Mix (Sigma-Aldrich) and quantified according to the $2^{\Delta \Delta \mathrm{Ct}}$ method. For these reactions, we used $0.5 \mu \mathrm{M}$ primers (Adra $2 a$ forward primer: 5'-AGCATCGGAAAGACGAACCG-3 ${ }^{\prime}$ and Adra $2 a$ reverse primer: 5'-GTGCAAAAGAGCACGTCGAG-3'). PCR products were confirmed in $1.5 \%$ agarose gels. Analysis of melting curves confirmed primer specificity. Each assay was run in triplicate and independently repeated $\geq 3$ times to verify the results. Data were normalized to the expression of the commonly used reference gene Tbp which encodes TATA-binding protein.

\section{Radioligand binding assays}

Radioligand binding and competition assays were conducted as previously described ${ }^{46}$. Briefly, adherent INS-1E cells expressing the endogenous $\alpha_{2 \mathrm{~A}}$-adrenergic receptors or transfected HEK-293 cells overexpressing human $\alpha_{2 A^{-}}$ adrenergic receptor were dissociated from plates, and intact cells collected by centrifugation (600-900 g, 5-10 min, $4{ }^{\circ} \mathrm{C}$ ). Cells were resuspended and lysed using $5 \mathrm{mM}$ Tris- $\mathrm{HCl}$ and $5 \mathrm{mM} \mathrm{MgCl}_{2}\left(\mathrm{pH} \mathrm{7.4,4}{ }^{\circ} \mathrm{C}\right)$. Cell lysates were pelleted by centrifugation at $30,000 \times g$ for 
30 min and resuspended in Earle's Balanced Salt Solution with $\mathrm{Ca}^{2+}(\mathrm{pH}$ 7.4). For saturation binding assays, cell lysates $(100 \mu \mathrm{L}, 2-5 \mu \mathrm{g}$ of protein for HEK-293 cells and $10-20 \mu \mathrm{g}$ of protein for INS-1E cells, quantified by the Bradford Assay) were incubated with the indicated concentrations of $\left[{ }^{3} \mathrm{H}\right] \mathrm{RX} 821002$ (90 min, room temperature). For competition binding assays, cell lysates were incubated with the indicated concentrations of DA, NE, yohimbine, or clonidine and $0.4-0.9 \mathrm{nM}\left[{ }^{3} \mathrm{H}\right] \mathrm{RX} 821002$ (90 min, room temperature). Nonspecific binding was determined in the presence of $10 \mu \mathrm{M}$ yohimbine. The bound ligand was separated from free ligand by filtration through a Perkin Elmer Unifilter-96 GF/C 96-well microplate using the Perkin Elmer Unifilter-96 Harvester (Perkin Elmer, Waltham, MA), followed by three washes with ice-cold assay buffer. After drying, a liquid scintillation cocktail (MicroScint PS; Perkin Elmer) was added to each well, and plates were sealed and analyzed on a Topcount NXT liquid scintillation counter (Perkin Elmer). $K_{\mathrm{i}}$ values were calculated from observed $\mathrm{IC}_{50}$ values using the Cheng-Prusoff equation ${ }^{47}$.

\section{NanoBRET \\ DNA constructs}

For nanoBRET experiments, we used receptor constructs consisting of either human D2R (DRD2) and rat $\alpha_{2 \mathrm{~A}}$-adrenergic receptor (Adra2a) cDNAs fused to HaloTag at the C-terminus $\left(\alpha_{2 \mathrm{~A}}\right.$-AR-HaloTag and D2RHaloTag). Both receptors were also tagged at the $\mathrm{N}$ terminus with an IL6 signal sequence followed by a HiBiT tag. For $\mathrm{G}$ protein and $\beta$-arrestin2 receptor recruitment studies, we used human $\mathrm{G \alpha}_{\mathrm{i} 1}$ with nanoluciferase (NanoLuc) inserted at position $91\left(\mathrm{NanoLuc}-\mathrm{G \alpha}_{\mathrm{i1}(91)}\right)$ and human $\beta$-arrestin 2 fused with NanoLuc at the $\mathrm{N}$ terminus (NanoLuc- $\beta$-arrestin2). All constructs were cloned into a pcDNA3.1(+) vector backbone (ThermoFisher Scientific) and confirmed by sequencing analysis.

\section{Transfection}

HEK-293T cells were cultured in 100-mm dishes and transfected upon $70 \%$ confluency. A constant amount of plasmid cDNA $(2.5 \mu \mathrm{g})$ was transfected into the HEK293T cells using Lipofectamine 3000 (ThermoFisher Scientific) according to the manufacturer's instructions. Our nanoBRET assays were performed to detect ligandinduced recruitment of $G \alpha_{i}$ or $\beta$-arrestin 2 to either $\alpha_{2 A^{-}}$ adrenergic receptor or D2R. Cells were co-transfected with the following optimized donor:acceptor nanoBRET pair ratios: $50\left(\alpha_{2 \mathrm{~A}}\right.$-AR-HaloTag): 1 (NanoLuc-G $\alpha_{\mathrm{i} 1(91)}$ or NanoLuc- $\beta$-arrestin2); and 100 (D2R-HaloTag): 1 $\left(\right.$ NanoLuc-G $\alpha_{i 1(91)}$ or NanoLuc- $\beta$-arrestin2). For NanoLuc-only controls, empty pcDNA3.1(+) vector was used to maintain a constant amount of total transfected DNA.

\section{NanOBRET}

Cells were harvested, washed, and resuspended in fresh medium $24 \mathrm{~h}$ post-transfection. Approximately $5 \times 10^{4}$ cells/well were distributed in pre-coated 96-well plates and allowed to adhere overnight $\left(37^{\circ} \mathrm{C}, 5 \% \mathrm{CO}_{2}\right)$. On an experimental day, cells were washed with Hanks' Balanced Salt Solution (HBSS, Gibco/ThermoFisher Scientific) and the respective receptors were labeled with $100 \mathrm{nM}$ HaloTag NanoBRET 618 ligand (Promega Corporation, Fitchburg, WI) in phenol red-free Opti-MEM I reduced serum medium (Gibco/ThermoFisher Scientific) $(2 \mathrm{~h}$, $37^{\circ} \mathrm{C}, 5 \% \mathrm{CO}_{2}$ ). Following labeling, cells were washed once with HBSS, and $5 \mu \mathrm{M}$ furimazine (substrate for NanoLuc) was added to every well. Drugs were then added to the samples and incubated for $12 \mathrm{~min}$. Plates were read $5 \mathrm{~min}$ following drug addition using a PheraStar FSX equipped with a nanoBRET-compatible optic module (LUM 610 450) (BMG Labtech). The nanoBRET ratio was calculated as the emission of the acceptor $(618 \mathrm{~nm})$ divided by the emission of the donor $(460 \mathrm{~nm})$. The nanoBRET signal from assay wells was corrected by subtracting the $618 \mathrm{~nm} / 460 \mathrm{~nm}$ ratio of cells co-expressing NanoLuc and HaloTag minus the nanoBRET ratio of cells expressing only the NanoLuc in the same experiment. The nanoBRET data were normalized to the \% maximum response of either $\mathrm{NE}$ for the $\alpha_{2 \mathrm{~A}}$-adrenergic receptor experiments or DA for the D2R experiments. NanoBRET data were further normalized to define the minimum and maximum response to the corresponding endogenous ligand, using the GraphPad Prism software package (version 7.02, GraphPad Software, San Diego, CA). EC 50 values were calculated via a non-linear regression analysis via GraphPad software.

\section{RNA-sequencing analyses}

Transcriptome analyses of human $\alpha$ - and $\beta$-cells were conducted using an RNA-sequencing data set that we recently established from dissociated and sorted human $\alpha$ - and $\beta$-cells isolated from non-diabetic human pancreata: ${ }^{48,49}$ human $\alpha$-cells (GEO: GSE106148) ${ }^{48}$; human $\beta$-cells (GEO: GSE116559) ${ }^{49}$. Mouse RNA-sequencing data was derived from an available data set: mouse $\alpha$ - and $\beta$-cells (GEO: GSE80673) ${ }^{50}$. To calculate the relative expression ratios of genes of interest within each cell type and species, we used the original gene counts from these RNA-sequencing data sets. Counts for genes of interest were normalized to derive expression values while accounting for potential differences in library size or read length bias. Ratios of genes of interest to $\operatorname{Drd} 2$ or $\operatorname{Drd} 3$ were calculated for $\alpha$ - and $\beta$-cells from human and mouse using the control samples within each cell type. The difference in ratios relative to $\operatorname{Drd} 2$ or $\operatorname{Drd} 3$ were calculated using the limma software package for each cell type for human and mouse, as described earlier ${ }^{51}$. 


\section{Statistical analyses}

GraphPad Prism (version 7.02) was used for all statistical analyses. Two-tailed $t$-tests were used to analyze HPLC results between L-DOPA-treated and untreated samples as well as between secreted and intracellular assay samples. Ordinary one-way ANOVA followed by Dunnett's multiple comparisons tests were used to analyze differences between the effects of drug treatments on glucagon or insulin secretion from islets. The variance was similar between the groups being statistically compared. Sample sizes were initially chosen on the basis of power analyses assuming an effect size of 0.60 , power level of 0.80 , and a probability level for statistical significance of 0.05 .

\section{Results}

Human and mouse pancreatic $\alpha$ - and $\beta$-cells express the catecholamine biosynthetic and catabolic machinery

To evaluate whether human and mouse $\alpha$-cells and $\beta$-cells express the machinery of catecholamine biosynthesis and catabolism, we analyzed an RNAsequencing (RNA-seq) data set that we recently established from human $\alpha$-cells and $\beta$-cells, alongside a comparable available RNA-seq data set from mouse $\alpha$-cells and $\beta$-cells ${ }^{48-50}$. We found both human and mouse $\alpha$ cells and $\beta$-cells express the complete catecholamine signaling machinery, though with major cell type- and species-specific differences (Fig. 1a, b); we confirmed celltype specificity with enrichment of $\alpha$-cell- and $\beta$-cellspecific markers (e.g., MAFA, ARX, IRX1, and IRX2) in the respective cell types (Supplementary Fig. S1a, b). Both human and mouse $\alpha$-cells and $\beta$-cells express the machinery for catecholamine biosynthesis including tyrosine hydroxylase $(T H)$, DOPA decarboxylase $(D D C)$, and dopamine $\beta$-hydroxylase $(D B H)$ (Fig. 1a, b). We also found human and mouse $\alpha$-cells and $\beta$-cells express the Ltype amino acid transporter (LAT) isoforms required for cellular uptake of catecholamine precursors (e.g., LDOPA). This includes $\alpha$-cell and $\beta$-cell expression of both components of the LAT1 heterodimer, LAT1 (SLC7A5) and CD98 (SLC3A2), as well as LAT2 (SLC7A8) (Fig. 1a, b). Similarly, both isoforms of the vesicular monoamine transporters VMAT1 (SLC18A1) and VMAT2 (SLC18A2) required for vesicular catecholamine uptake are expressed in human and mouse $\alpha$ - and $\beta$-cells (Fig. 1a, b). Additionally, in human $\alpha$-cells and $\beta$-cells, we detected the expression of the dopamine transporter (DAT, SLC6A3), which enables DA uptake into these cells. In contrast, we found comparatively lower expression of the norepinephrine transporter (NET, SLC6A2) in $\alpha$-cells and $\beta$-cells (Fig. 1a, b). Lastly, the catabolic machinery, including monoamine oxidase $\mathrm{A}$ and $\mathrm{B}(M A O A, M A O B)$ and catechol-O-methyltransferase (COMT), is expressed in human and mouse $\alpha$-cells and $\beta$-cells (Fig. 1a, b).

\section{Pancreatic a-cells synthesize and secrete DA, NE, and L- DOPA}

We examined whether $\alpha$-cells produce and secrete DA using $\alpha \mathrm{TC} 1-6$ cells, a glucagon-secreting mouse $\alpha$-cell line ${ }^{52}$. We and others previously showed that rodent $\beta$-cells do not synthesize significant L-DOPA or DA de novo, but produce ample quantities of DA in response to uptake of exogenous L-DOPA ${ }^{6,7,9}$. In contrast, we found $\alpha \mathrm{TC} 1-6$ cells produce and secrete L-DOPA de novo as well as convert it to DA and NE (Fig. 1c). As in $\beta$-cells ${ }^{7}$, exogenous L-DOPA supplementation $(10 \mu \mathrm{M})$ promotes a substantial 60-fold increase in $\alpha$-cell DA secretion $(P<$ $0.0001)$. However, NE is increased only 3 -fold in response to L-DOPA addition compared to untreated cells $(P=$ 0.0004; Fig. 1d). These results suggest $\alpha$-cells can adjust catecholamine production based on precursor availability and that this mechanism is preferentially geared towards DA synthesis and release. Additionally, metabolites homovanillic acid (HVA) (Fig. 1e) and 3,4 dihydroxyphenylacetic acid (DOPAC) (Fig. 1f) are produced and secreted, indicating $\alpha$-cell COMT and MAO activity, respectively. We also observed that $\mathrm{MAO}$ inhibitors (10 $\mu \mathrm{M}$ of deprenyl, pargyline, and clorgyline) increase secreted DA $\sim 3$-fold relative to untreated cells $(P<$ 0.0001; Fig. 1g), further confirming MAO activity in $\alpha-$ cells.

\section{DA differentially modulates glucagon and insulin secretion in mouse and human islets}

Since $\alpha$-cells produce DA and NE, we examined whether these catecholamines regulate glucagon secretion. We found NE produces a dose-dependent stimulation of glucagon secretion in mouse islets $\left(E_{50}=142 \pm 2.3 \mathrm{nM}\right.$; Fig. 2a), consistent with earlier studies $^{53,54}$. Similarly, increasing NE concentrations significantly enhance glucagon secretion in human islets from non-diabetic donors (Supplementary Table S1 and Fig. 2b).

We found that DA also modulates $\alpha$-cell glucagon secretion, though with important species-specific differences. Whereas DA enhances glucagon release from mouse islets in a monophasic manner $\left(\mathrm{EC}_{50}=14.9 \pm\right.$ $3.8 \mathrm{nM}$; Fig. 2c), we observed a biphasic glucagon secretory response to DA in human islets (Fig. 2d): low DA concentrations $(100 \mathrm{pM}-1 \mu \mathrm{M})$ reduce glucagon secretion $(P=0.03)$, while higher DA concentrations $(10-100 \mu \mathrm{M})$ enhance glucagon release $(P=0.03)$ (Fig. $2 \mathrm{~d})$. We examined insulin secretion from the same mouse and human islets, finding that $\mathrm{NE}$ reduces insulin secretion in a monophasic manner in both mice $\left(\mathrm{IC}_{50}=179 \pm\right.$ $2.4 \mathrm{nM}$; Fig. $2 \mathrm{e})$ and human islets $\left(\mathrm{IC}_{50}=787 \pm 1.3 \mathrm{nM}\right.$; Fig. 2f). DA also dose-dependently inhibits insulin secretion in mouse islets, though with $\sim 7$-fold lower potency compared to $\mathrm{NE} \quad\left(\mathrm{IC}_{50}=1.3 \pm 0.002 \mu \mathrm{M}\right.$; Fig. 2g). 
a

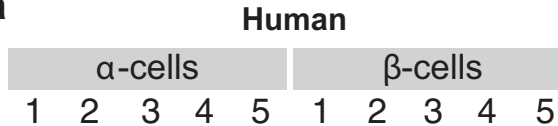
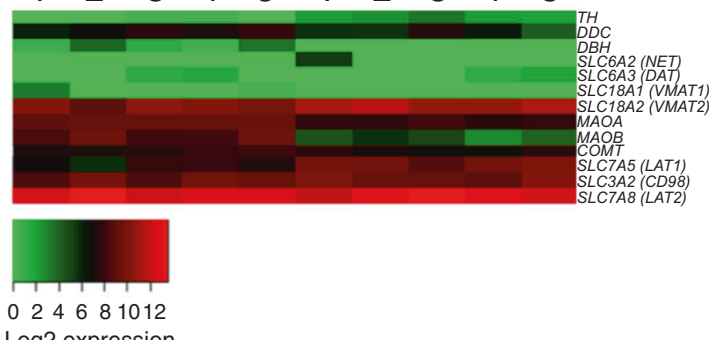

C
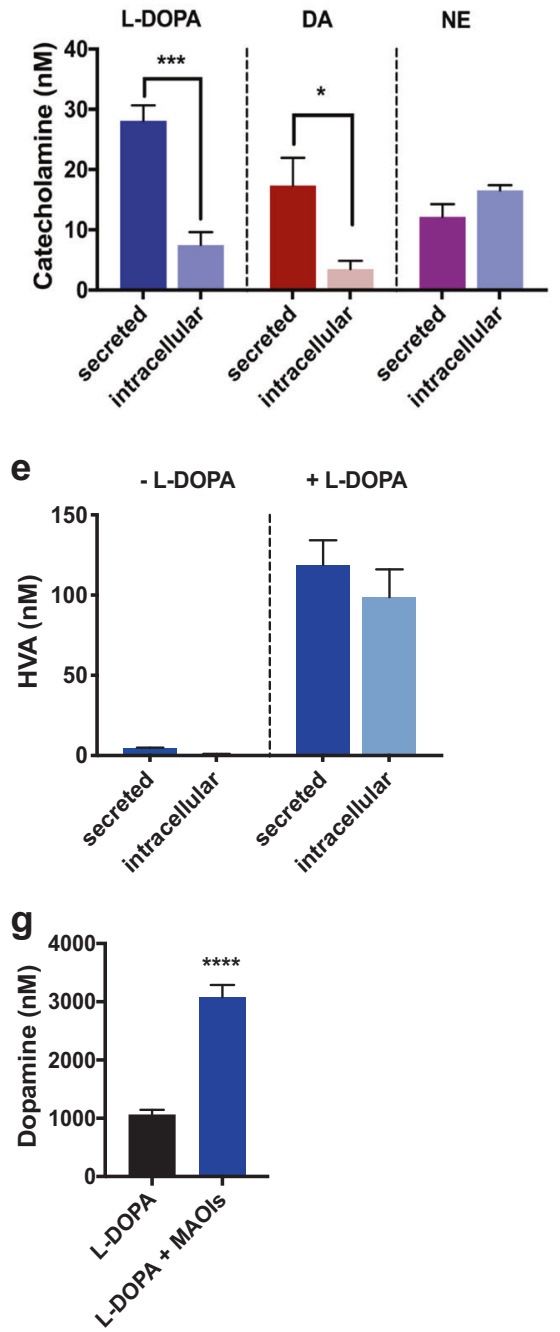

b

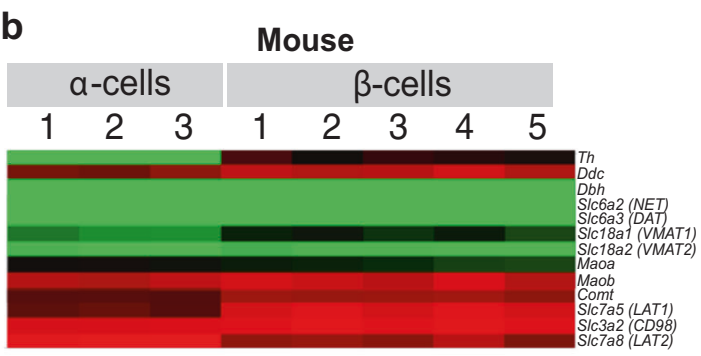

0123456

Log2 expression

d

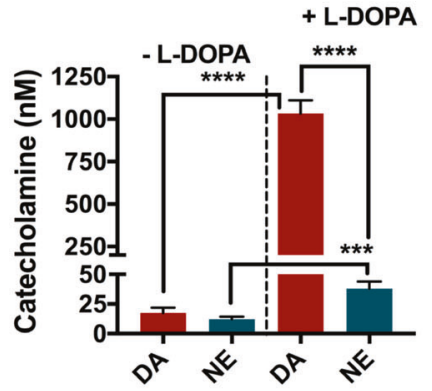

f

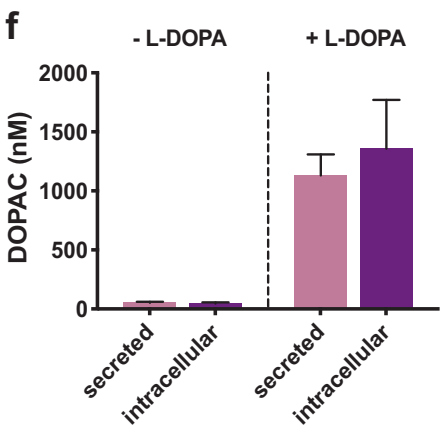

Fig. 1 (See legend on next page.)

Additionally, we found that DA inhibits insulin release in human islets $\left(\mathrm{IC}_{50}=26.2 \pm 2.9 \mathrm{nM}\right.$; Fig. $\left.2 \mathrm{~h}\right)$ and that this inhibition is monophasic, unlike the DA's biphasic glucagon response.
Differences in DA and NE receptor expression in mouse and human islet $\boldsymbol{\alpha}$ - and $\boldsymbol{\beta}$-cells

Recent evidence suggests that DA can signal not only through $\mathrm{D}_{2}$-like receptors, but also via adrenergic 
(see figure on previous page)

Fig. 1 Human and mouse pancreatic $\alpha$ - and $\beta$-cells express the catecholaminergic machinery with $a$-cell production of catecholamines and metabolites. $\mathbf{a}$, $\mathbf{b}$ Transcriptome by RNA-sequencing analysis of purified $\mathbf{a}$ - and $\beta$-cells from pancreatic islets from $\mathbf{a}$ non-diabetic human donors $(n$ =5; ages 26-55 years) and $\mathbf{b}$ mouse. Heatmaps of a selected gene subset focusing on the catecholamine biosynthetic, transport, and vesicular packaging machinery show relative gene expression values in individual $a$ - and $\beta$-cell samples of dopaminergic and adrenergic receptors as well as the complete catecholamine biosynthetic and catabolic machinery. c HPLC analyses of supernatants and lysates from a-cell-derived aTC1-6 cells demonstrating the synthesis of L-DOPA, DA, and NE de novo in the absence of catecholamine precursor supplementation. Cells secreted most intracellular L-DOPA and DA with significantly lower L-DOPA $(P=0.0002)$ or DA $(P<0.05)$ in lysates compared to supernatants. $\mathbf{d} H P L C$ analyses show that pre-incubation with $10 \mu \mathrm{M}$ L-DOPA significantly enhanced a-cell DA and NE production and secretion. Though L-DOPA supplementation boosted NE production ( $P=0.0004)$, DA production was preferentially boosted over NE, with DA levels 27-fold more compared to NE $(P<0.0001)$. e, $\mathbf{f}$ In aTC1-6 cells, both secreted and intracellular levels of DA metabolites HVA (e) and DOPAC (f) were substantially enhanced in response to $10 \mu \mathrm{M} L-$ DOPA supplementation. $\mathbf{g}$ Treatment of aTC1-6 cells with a cocktail of monoamine oxidase inhibitors (MAOls: $10 \mu \mathrm{M}$ of deprenyl, pargyline, and clorgyline, respectively) significantly enhanced DA synthesis in response to L-DOPA supplementation (blue bar) compared to the $10 \mu \mathrm{M}$ L-DOPA alone condition ( $P<0.0001$, gray bar). Assay points were carried out in triplicates from $n \geq 2$ independent experiments. Data are represented as mean \pm SEM; two-tailed Student's $t$-test $(\mathbf{c}, \mathbf{d}, \mathbf{g}){ }^{*} P<0.05,{ }^{* * *} P<0.001,{ }^{* * * *} P<0.0001$.

receptors, albeit with different potencies ${ }^{46}$. Importantly, both dopaminergic and adrenergic receptor subtypes are co-expressed in human and rodent $\alpha$-cells and $\beta$-cells ${ }^{5,7,9,22,23}$. Therefore, we compared cell type- and species-specific expression of $\alpha$ - and $\beta$-adrenergic receptor subtypes relative to either D2R or D3R using our human and mouse $\alpha$-cell and $\beta$-cell RNA-seq data sets. We found substantial differences in the expression of $D_{2}$ like and adrenergic receptors in mouse versus human $\alpha$ cells and $\beta$-cells (Supplementary Fig. S2). $\beta_{1}$-adrenergic receptor and D2R are expressed at similar levels in human $\alpha$-cells (e.g., $\beta_{1}$-adrenergic receptor $/ \mathrm{D} 2 \mathrm{R}$ ratio $=1.25$; Supplementary Fig. S2a), while there is 74-fold higher expression of $\beta_{1}$-adrenergic receptor relative to D2R in mouse $\alpha$-cells (Supplementary Fig. S2b). Likewise, in human $\beta$-cells, $\alpha_{2 \mathrm{~A}}$-adrenergic receptor is only 1.5 -fold more expressed than D2R (Supplementary Fig. S2a) but, in mouse $\beta$-cells, $\alpha_{2 \mathrm{~A}}$-adrenergic receptor is 1,395 -fold more expressed compared to D2R (Supplementary Fig. $\mathrm{S} 2 \mathrm{~b})$. We found similar expression ratios comparing adrenergic receptors relative to D3R in mouse versus human $\alpha$ - and $\beta$-cells (Supplementary Fig. S2c, d).

Based on these relative differences in receptor expression, we hypothesized that in human $\alpha$-cells, DA promotes a biphasic glucagon response by activating: (1) inhibitory $\mathrm{D}_{2}$-like receptors that readily bind $\mathrm{DA}$ at lower concentrations, which leads to secretory inhibition; and (2) stimulatory $\beta$-adrenergic receptors that are more effectively activated by DA at higher concentrations, resulting in enhanced glucagon release. In contrast, since mouse $\alpha$-cells mainly express stimulatory $\beta_{1}$-adrenergic receptors, DA primarily stimulates glucagon secretion. Thus, the predominantly expressed $\beta_{1}$-adrenergic receptors will mask any potential inhibition from DA's activation of $\mathrm{D}_{2}$-like receptors, which are expressed at much lower levels. This would explain the observed monophasic enhancement of glucagon release (Fig. 2c). Dopaminergic stimulation of adrenergic receptors also extends to $\beta$-cells.
Because mouse $\beta$-cells express far more inhibitory $\alpha_{2 A^{-}}$ adrenergic receptors relative to D2R or D3R (Supplementary Fig. S2), our data suggest that DA primarily acts on mouse $\alpha_{2 \mathrm{~A}}$-adrenergic receptors which also diminish insulin release. On the other hand, human $\beta$-cells express considerably more $\mathrm{D}_{2}$-like receptors compared to mouse $\beta$-cells; levels of $D_{2}$-like receptors and $\alpha_{2 \mathrm{~A}}$-adrenergic receptors are similar in human $\beta$-cells. Since human $\beta$-cell $D_{2}$-like receptors can be activated by DA at presumably lower concentrations than $\alpha_{2 \mathrm{~A}}$-adrenergic receptors, this may account for DA's 50-fold higher potency for decreasing insulin secretion in human islets compared to mouse (Fig. 2g, h).

\section{DA acts via adrenergic receptors to regulate hormone secretion in pancreatic islets}

We functionally tested DA's ability to directly signal through islet adrenergic receptors to modulate hormone secretion. Since the $\beta_{1}$-adrenergic receptor is the predominant catecholamine receptor subtype expressed in mouse $\alpha$-cells, we pre-treated mouse islets with the $\beta$-adrenergic antagonist propranolol $(100 \mathrm{nM})$ prior to DA treatment. We found that propranolol attenuates DA's enhancement of glucagon secretion (Fig. 3a). This suggests that DA mainly acts on $\beta_{1}$-adrenergic receptors in mouse $\alpha$-cells to modulate glucagon secretion, potentially masking contributions from the less abundant DA receptors also expressed in these cells.

To dissect DA signaling via dopaminergic versus adrenergic receptors in $\beta$-cells, we deleted the $\alpha_{2 \mathrm{~A}}$-adrenergic receptor via CRISPR-Cas9 in rodent $\beta$-cell-derived INS$1 \mathrm{E}$ cells. We generated a series of clonal lines and selected a complete $\alpha_{2 \mathrm{~A}}$-adrenergic receptor knockout (KO) line based on the total loss of receptor mRNA expression by qPCR (Supplementary Fig. S3a). We also functionally validated this $\alpha_{2 \mathrm{~A}}$-adrenergic receptor $\mathrm{KO}$ cell line by testing the effects of clonidine, a selective $\alpha$-adrenergic receptor agonist, on GSIS. While clonidine potently 
a

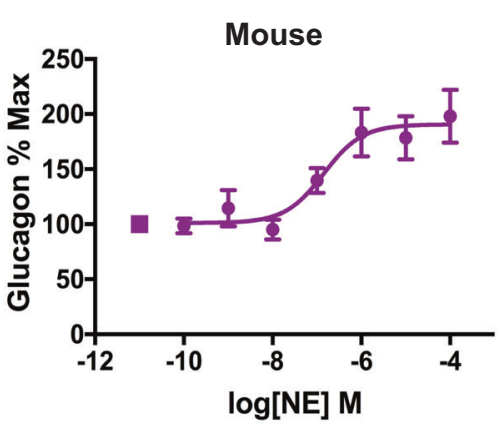

C

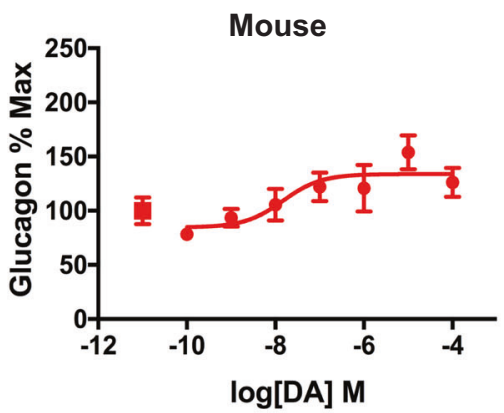

e

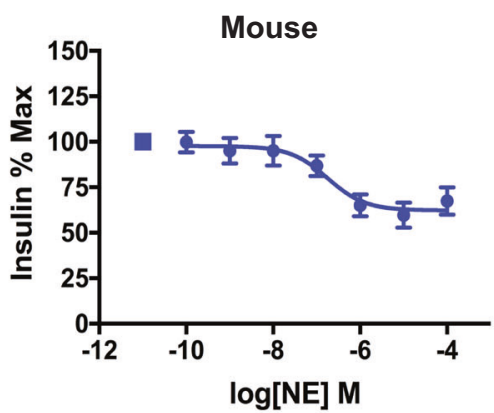

g

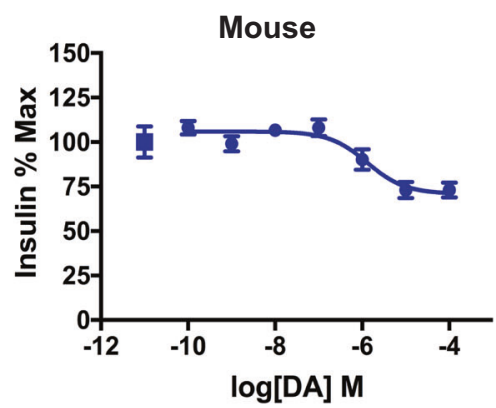

b

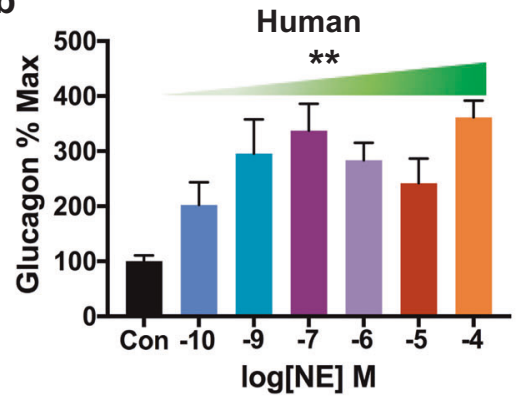

d

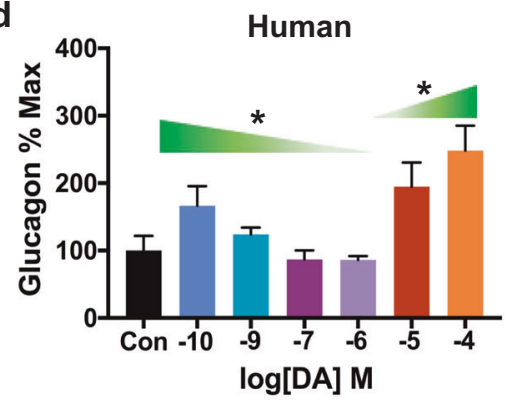

f

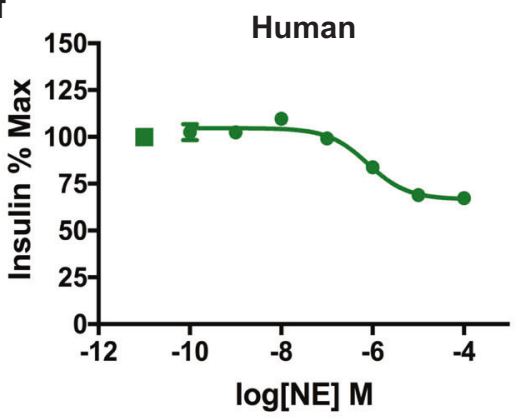

h

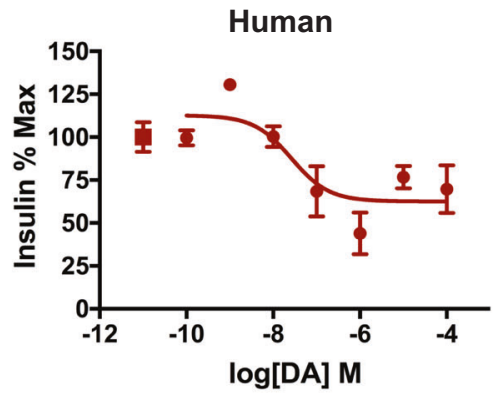

Fig. 2 Dopamine and norepinephrine modulate glucagon and insulin secretion in human and mouse islets. a Treatment with norepinephrine (NE) produced a dose-dependent increase in secreted glucagon $\left(\mathrm{EC}_{50}=141.7 \pm 2.3 \mathrm{nM}, R^{2}=0.91\right)$ in mouse islets. $\mathbf{b}$ In human islets, NE treatment also significantly increased a-cell glucagon secretion relative to the vehicle control (Con) $[F(6,34)=4.083, P=0.003]$. c In mouse islets, treatment with dopamine (DA) dose-dependently enhanced a-cell glucagon secretion $\left(E C_{50}=14.9 \pm 3.8 \mathrm{nM}, R^{2}=0.87\right)$ in a monophasic manner. $\mathbf{d}$ In human islets, DA produced a biphasic glucagon response. Low DA concentrations (100 pM-1 $\mu \mathrm{M})$ progressively diminished a-cell glucagon secretion relative to the vehicle control (Con) $[F(4,22)=3.253 ; P=0.03]$. High DA concentrations $(10-100 \mu \mathrm{M})$ enhanced glucagon secretion compared to vehicle control $[F(2,12)=5.448 ; P=0.02]$. e, $\mathbf{f} N E$ reduced glucose-stimulated insulin secretion (GSIS) from $\beta$-cells in a concentration-dependent manner in: e mouse islets $\left(I C_{50}=178.5 \pm 2.4 \mathrm{nM}, R^{2}=0.91\right)$, and $\mathbf{f}$ human islets $\left(I_{50}=787.2 \pm 1.3 \mathrm{nM}, R^{2}=0.86\right)$. $\mathbf{g}, \mathbf{h}$ DA reduced GSIS in $\mathbf{g}$ mouse islets $\left(I C_{50}=1.29 \pm\right.$ $\left.0.002 \mu \mathrm{M}, R^{2}=0.83\right)$ and $\mathbf{h}$ in human islets $\left(\mathrm{IC}_{50}=26.2 \pm 2.9 \mathrm{nM}, R^{2}=0.89\right)$. All secretion assays were performed in triplicate from $n \geq 3$ independent experiments. Representative experiments are shown for all human islet hormone secretion experiments. Glucagon data normalized to \% maximal secreted glucagon; insulin data normalized to \% maximal secreted insulin. In a, c, e-h squares represent vehicle-treated controls. Data are represented as means for all experimental replicates \pm SEM; one-way ANOVA followed by Dunnett's multiple comparisons test $(\mathbf{b}, \mathbf{d}) .{ }^{*} P<0.05,{ }^{* *} P<0.01$. 


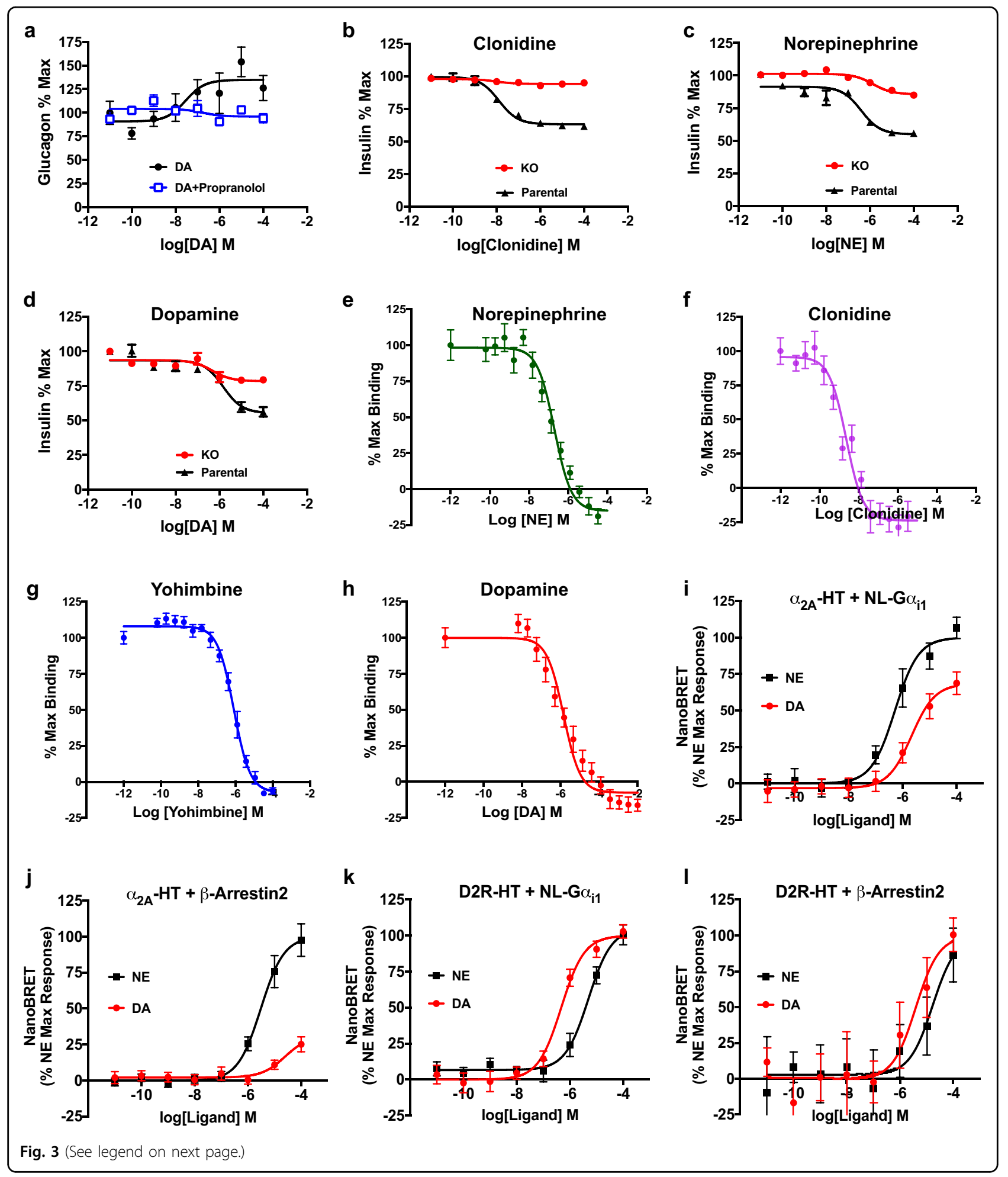

reduces GSIS in the parental INS-1E cell line $\left(\mathrm{IC}_{50}=\right.$ $12.7 \pm 1.3 \mathrm{nM}$ ), the drug's GSIS inhibition is virtually eliminated in the $\alpha_{2 \mathrm{~A}}$-adrenergic receptor $\mathrm{KO}$ cells (Fig. 3b and Supplementary Table S2). Clonidine's small residual effects on GSIS in the $\mathrm{KO}$ cells are likely due to the drug's actions on remaining $\alpha_{2}$-adrenergic receptors including $\alpha_{2 C}$-adrenergic receptors which play a small role in inhibiting GSIS in $\beta$-cells ${ }^{55,56}$. Like clonidine, NE also 
(see figure on previous page)

Fig. 3 Dopamine signals through the adrenergic system to modulate insulin and glucagon secretion. a $\beta$-adrenergic receptor antagonist propranolol $(100 \mathrm{nM})$ eliminated DA-induced increases in a-cell glucagon secretion from mouse islets (in blue) compared to treatment with DA alone (in black; $E C_{50}=14.9 \pm 3.8 \mathrm{nM}, R^{2}=0.68$ ). Glucagon data were normalized to \% maximal secreted glucagon. b CRISPR-Cas9-mediated knockout (KO) of endogenously expressed $a_{2 A}$-adrenergic receptors in insulin-secreting INS-1E cells (in red) attenuated clonidine's ability to diminish glucosestimulated insulin secretion (GSIS) compared to the parental INS-1E cells (in black; IC $C_{50}=12.7 \pm 1.3 \mathrm{nM}, R^{2}=0.92$ ). c Efficacy of GSIS inhibition by norepinephrine (NE) was diminished 2.9-fold along with decreased potency in the $\mathrm{a}_{2 \mathrm{~A}}$-adrenergic receptor KO cells (in red; $\mathrm{IC}_{50}=1.4 \pm 0.002 \mathrm{nM}, R^{2}$ $=0.70$ ) compared to the parental INS-1E cells (in black; $I_{50}=39.8 \pm 1.5 \mathrm{nM}, R^{2}=0.90$ ). $\mathbf{d}$ Efficacy of dopamine (DA)-induced GSIS inhibition was reduced 2.4-fold, while potency was increased in the $a_{2 A}$-adrenergic receptor $\mathrm{KO}$ cells (in red; $I_{50}=474 \pm 2.5 \mathrm{nM}, R^{2}=0.75$ ) compared to the parental INS-1E cells (in black; $I C_{50}=1.5 \pm 0.002 \mu \mathrm{M}, R^{2}=0.89$ ). For $\mathbf{b}-\mathbf{d}$, insulin data was normalized to \% maximal secreted insulin. e-h Radioligand binding of adrenergic and dopaminergic ligands to endogenous $a_{2}$-adrenergic receptors in INS-1E cells. Competition curves of $a_{2 A}$-adrenergic receptor $\left.{ }^{3} \mathrm{H}\right] \mathrm{RX} 821002$ versus increasing concentrations of free competitors: e NE $\left(K_{\mathrm{i}}=22.5 \pm 1.2 \mathrm{nM}\right) ; \mathbf{f}$ clonidine $\left(K_{\mathrm{i}}=0.27 \pm 0.001 \mathrm{nM}\right) ; \mathbf{g}$ yohimbine $\left(K_{\mathrm{i}}=92.2 \pm 1.1 \mathrm{nM}\right) ; \mathbf{h} \mathrm{DA}\left(K_{\mathrm{i}}=164 \pm 1.2 \mathrm{nM}\right)$. Radioligand experiments were normalized to \% maximal binding with all assays performed in triplicate in $n \geq 3$ independent experiments. Error bars $=S E M$. $\mathbf{i}-\mathbf{I}$ Concentration-response nanoBRET assays examining ligand-stimulated $\mathrm{G}$ protein and $\beta$-arrestin2 receptor recruitment in HEK-293T cells transiently transfected with either HaloTag-labeled $a_{2 A}$-adrenergic receptor $\left(a_{2 A}-H T\right)$ or D2R (D2R$\mathrm{HT}$ ) and NanoLuc-labeled $\mathrm{Ga}_{\mathrm{i} 1}\left(\mathrm{NL}-\mathrm{Ga}_{\mathrm{i}}\right)$ versus $\beta$-arrestin2 (NL- $\beta$-arrestin2) as the respective nanoBRET pairs. $\mathbf{i}$ DA treatment caused dose-dependent $\mathrm{Ga}_{\mathrm{i} 1}$ recruitment to $\mathrm{a}_{2 \mathrm{~A}}$-adrenergic receptor, albeit with reduced potency and efficacy compared to NE (DA: in red, $E C_{50}=2.1 \pm 0.002 \mu \mathrm{M}, R^{2}=0.77$; NE: in black, $\left.\mathrm{EC}_{50}=520 \pm 1.4 \mathrm{nM}, E_{\max }=71.5 \%, R^{2}=0.82\right)$. $\mathbf{j ~ N E}$ treatment produced dose-dependent increases in $\beta$-arrestin2 recruitment to $a_{2 A^{-}}$ adrenergic receptor (in black, $\mathrm{EC}_{50}=3.1 \pm 0.001 \mu \mathrm{M}, R^{2}=0.72$ ), while DA produced a negligible response (in red). $\mathbf{k}$ DA and NE treatments both resulted in comparable $\mathrm{Ga}_{\mathrm{i} 1}$ recruitment to $\mathrm{D} 2 \mathrm{R}$, with $\mathrm{DA}$ more potent $\left(\mathrm{DA}\right.$ in red; $\left.\mathrm{EC}_{50}=471 \pm 1.3 \mathrm{nM}, R^{2}=0.82\right)$ than $\mathrm{NE}$ ( $\mathrm{NE}$ in black; $E C_{50}=4.9 \pm$ $\left.0.001 \mu \mathrm{M}, R^{2}=0.67\right)$. I Both DA and NE treatments stimulated $\beta$-arrestin2 recruitment to $\mathrm{D} 2 \mathrm{R}$ with $\mathrm{DA}$ more potent $\left(\mathrm{DA}\right.$ in red; $E C_{50}=3.9 \pm 0.003 \mu \mathrm{M}$, $R^{2}=0.67$ ) compared to NE (NE in black; $\mathrm{EC}_{50}=16.8 \pm 0.004 \mu \mathrm{M}, R^{2}=0.63$ ). NanoBRET data were baseline-corrected by subtracting the nanoBRET ratio from the NanoLuc-only wells from the ratio calculated from assay wells expressing both NanoLuc and HaloTag. Results for $a_{2 A}$-adrenergic receptor recruitment were normalized to \% maximal NE response; data for D2R recruitment were normalized to \% maximal DA response. Data are represented as means \pm SEM for all experimental replicates and were performed in triplicate from $n \geq 3$ independent experiments.

dose-dependently reduces GSIS in the parental INS-1E cells $\left(\mathrm{IC}_{50}=39.8 \pm 1.5 \mathrm{nM}\right.$; Fig. 3c). Unlike clonidine, though NE's efficacy and potency are significantly diminished (35-fold decrease in efficacy, $\mathrm{IC}_{50}=1.4 \pm$ $0.002 \mu \mathrm{M})$, NE's GSIS inhibition is not entirely eliminated in the KO cells (Fig. 3c). This suggests that NE acts at additional catecholamine receptors, albeit with lower potency. DA's efficacy in inhibiting GSIS inhibition is also reduced (2.4-fold) but not eliminated in the KO cells compared to the parental line (Fig. 3d). DA's potency is greatly increased in the $\mathrm{KO}$ cells $\left(\mathrm{IC}_{50}=474 \pm 2.5 \mathrm{nM}\right)$ compared to the parental INS-1E cells $\left(\mathrm{IC}_{50}=1.5 \pm\right.$ $0.002 \mu \mathrm{M})$. Together, these data suggest that much of DA's efficacy in reducing GSIS is attributable to its actions on $\alpha_{2 \mathrm{~A}}$-adrenergic receptors in $\beta$-cells. Importantly, the deletion of the $\alpha_{2 \mathrm{~A}}$-adrenergic receptor in the KO cells unmasks the higher potency of DA for D2R, also expressed in INS-1E cells ${ }^{5}$, and reveals the relative contribution of D2R in the regulation of GSIS (Supplementary Table S2).

\section{DA binds to endogenous $\beta$-cell $\alpha_{2 A}$-adrenergic receptors}

We conducted radioligand binding studies employing the $\alpha_{2}$-adrenergic receptor antagonist $\left[{ }^{3} \mathrm{H}\right] \mathrm{RX} 821002$ to determine the binding affinity of DA at endogenous $\beta$-cell $\alpha_{2 \mathrm{~A}}$-adrenergic receptors. We first confirmed the binding of $\left[{ }^{3} \mathrm{H}\right] \mathrm{RX} 821002$ at $\alpha_{2 \mathrm{~A}}$-adrenergic receptors using membranes from HEK-293 cells overexpressing $\alpha_{2 \mathrm{~A}}$-adrenergic receptors and determined the binding affinity $\left(K_{\mathrm{D}}=\right.$
$0.67 \pm 0.05 \mathrm{nM})$ and $B_{\max }(5691 \pm 103 \mathrm{fmol} / \mathrm{mg}$ protein $)$ values (Supplementary Fig. S3b). Competition experiments of $\left[{ }^{3} \mathrm{H}\right]$ RX821002 with $\alpha_{2}$-adrenergic receptor antagonist yohimbine and DA, in the same $\alpha_{2 \mathrm{~A}}$-adrenergic receptoroverexpressing HEK-293 cells, demonstrated that both yohimbine and DA displace $\left[{ }^{3} \mathrm{H}\right] \mathrm{RX} 821002$ with differing affinities: nanomolar affinity for yohimbine $\left(K_{\mathrm{i}}=38.2 \pm\right.$ $1.1 \mathrm{nM})$ and micromolar affinity for DA $\left(K_{\mathrm{i}}=22.1 \pm\right.$ $0.001 \mu \mathrm{M})$ (Supplementary Fig. S3c). This suggests that DA targets $\alpha_{2 \mathrm{~A}}$-adrenergic receptors as a lower-affinity substrate compared to a classical $\alpha_{2}$-adrenergic receptorligand like yohimbine. We also compared the binding of $\left[{ }^{3} \mathrm{H}\right] \mathrm{RX} 821002$ at endogenous $\alpha_{2 \mathrm{~A}}$-adrenergic receptors expressed in the parental INS-1E cells versus the $\alpha_{2 \mathrm{~A}^{-}}$ adrenergic receptor $\mathrm{KO}$ cells. Our studies confirm substantially diminished radioligand binding in membranes from the $\mathrm{KO}$ cells $\left(B_{\max }=29.1 \pm 4.3 \mathrm{fmol} / \mathrm{mg}\right.$ protein $)$ relative to the parental INS-1E cells $\left(B_{\max }=110 \pm 3.3\right.$ $\mathrm{fmol} / \mathrm{mg}$ protein) (Supplementary Fig. S3d). We next determined binding affinities of several $\alpha_{2}$-adrenergic receptor ligands (NE, clonidine, yohimbine) to endogenous $\alpha_{2 \mathrm{~A}}$-adrenergic receptors in INS-1E cells using the calculated $K_{\mathrm{D}}$ from the saturation binding experiments in these cells $\left(K_{\mathrm{D}}=0.10 \pm 0.02 \mathrm{nM}\right)$ (Supplementary Fig. S3d and Supplementary Table S3). NE (Fig. 3e), clonidine (Fig. 3f), and yohimbine (Fig. 3g) all displace $\left[{ }^{3} \mathrm{H}\right] \mathrm{RX} 821002$ in competition experiments using INS-1E cell membranes (NE: $K_{\mathrm{i}}=22.5 \pm 1.2 \mathrm{nM}$; Clonidine: $K_{\mathrm{i}}=0.27 \pm 0.001 \mathrm{nM}$; yohimbine: $K_{\mathrm{i}}=92.2 \pm 1.1 \mathrm{nM}$ ). Significantly, DA also 
successfully displaces $\left[{ }^{3} \mathrm{H}\right] \mathrm{RX} 821002$ from endogenous receptors $\left(K_{\mathrm{i}}=164 \pm 1.2 \mathrm{nM}\right.$; Fig. 3h), validating DA's ability to bind endogenously expressed $\alpha_{2 \mathrm{~A}}$-adrenergic receptor. Our data demonstrate an order of affinity of clonidine $>\mathrm{NE}>$ yohimbine $>\mathrm{DA}$ and suggest that $\alpha_{2 \mathrm{~A}^{-}}$ adrenergic receptors can serve as both low-affinity targets for DA and high-affinity targets for classical $\alpha_{2}$-adrenergic ligands like NE, clonidine, and yohimbine.

\section{DA is a $\mathrm{Ga}_{\mathrm{i}}$-biased ligand at $\mathrm{a}_{2 \mathrm{~A}}$-adrenergic receptors}

We determined whether DA and NE differ in their abilities to initiate intracellular signaling upon activation of D2R and $\alpha_{2 A}$-adrenergic receptors. Using nanoBRET technology, we focused on ligand-stimulated receptor recruitment of $G \alpha_{i}$ and $\beta$-arrestin2, initiators of $G$ protein-dependent and $G$ protein-independent signaling pathways, respectively ${ }^{56} \cdot \alpha_{2 \mathrm{~A}}$-adrenergic receptors were labeled with HaloTag, and either $\mathrm{G \alpha}_{\mathrm{i} 1}$ or $\beta$-arrestin2 were labeled with the highly-sensitive nanoluciferase (NanoLuc) as the nanoBRET pair. We found that $\alpha_{2 \mathrm{~A}}$-adrenergic receptor activation by DA or NE results in $\mathrm{G \alpha}_{\mathrm{i} 1}$ recruitment to the receptor, with NE showing higher potency $\left(\mathrm{EC}_{50}=520 \pm 1.4 \mathrm{nM}\right)$ and efficacy compared to DA $\left(\mathrm{EC}_{50}=2.1 \pm 0.002 \mu \mathrm{M}\right.$; Fig. 3i). Significantly, while NE stimulation causes receptor recruitment of $\beta$-arrestin2 $\left(\mathrm{EC}_{50}=3.1 \pm 0.001 \mu \mathrm{M}\right.$ ), DA stimulation does not (Fig. $3 j)$. To exclude potential kinetic differences in the ability of DA to recruit $\beta$-arrestin2 versus $\mathrm{G \alpha}_{\mathrm{i} 1}$, time-course experiments showed that receptor stimulation by DA does not result in the recruitment of $\beta$-arrestin2 at any of the time points tested (data not shown). By comparison, stimulation of D2R by either DA or NE leads to recruitment of both $G \alpha_{i 1}$ and $\beta$-arrestin2, with DA showing higher potency than $\mathrm{NE}\left(\mathrm{G \alpha}_{\mathrm{i} 1}\right.$ : DA $\mathrm{EC}_{50}=471 \pm 1.3 \mathrm{nM}, \mathrm{NE}$ $\mathrm{EC}_{50}=4.9 \pm 0.001 \quad \mu \mathrm{M} ; \quad \beta$-arrestin2: $\quad \mathrm{EC}_{50}=3.9 \pm$ $0.003 \mu \mathrm{M}, \quad \mathrm{NE} \quad \mathrm{EC}_{50}=16.8 \pm 0.004 \mu \mathrm{M}$ ) (Fig. 3k, l). Overall, our results suggest that DA functions uniquely at $\alpha_{2 \mathrm{~A}}$-adrenergic receptors as a $\mathrm{G}$ protein-biased agonist by selectively directing intracellular signaling towards G protein-mediated transduction pathways.

\section{APDs increase $a$-cell glucagon and $\beta$-cell insulin secretion in human islets}

We determined the effects of $D_{2}$-like receptor antagonism on $\alpha$-cell glucagon and $\beta$-cell insulin secretion in human islets using the APDs haloperidol, olanzapine, and clozapine. All three APDs significantly increase $\alpha-$ cell glucagon release (Fig. 4a). Compared to vehicle, clozapine raises glucagon secretion most $(200.2 \pm 21.7 \%$ increase, $P<0.0001)$, followed by olanzapine $(105.7 \pm$ 23.4\% increase, $P=0.0002)$ and haloperidol $(67.1 \pm$ $13.6 \%$ increase, $P<0.0001$ ) (Fig. 4a). In parallel, these APDs also significantly increase GSIS from the same human islets compared to the vehicle: clozapine (19.8 \pm
$4.0 \%$ increase, $P=0.0006)$, olanzapine $(43.6 \pm 3.1 \%$ increase, $\quad P<0.0001), \quad$ and haloperidol $(24.1 \pm 4.6$ increase, $P=0.0004$ ) (Fig. 4b). Importantly, our findings in human islets are consistent with earlier reports of APD-induced hyperinsulinemia and hyperglucagonemia in both rodent models and in humans ${ }^{19,21,41,57}$. Overall, these results strongly suggest that APDs act directly on both $\alpha$ - and $\beta$-cells to disrupt the regulation of glucagon and insulin secretion. In $\beta$-cells, APDs block inhibitory $\mathrm{D}_{2}$-like receptors, leading to increased insulin secretion. In parallel, APDs disrupt inhibitory $\alpha$-cell $D_{2}$-like receptor signaling and elevate glucagon release, resulting in hyperglycemia that may further exacerbate insulin resistance (Fig. 4c).

\section{Discussion}

DA signaling in the periphery is increasingly recognized as having critical roles in metabolic regulation $^{3,4,7,30,33,34,58,59}$. Our results offer new insights into outstanding questions concerning the sources of DA and its related catecholamine $\mathrm{NE}$ for local $\alpha$-cell and $\beta$-cell adrenergic and dopaminergic signaling in the pancreas. Historically, peripheral catecholamine signaling in the pancreas focused primarily on autonomic innervation of islets $^{26,27,60}$. NE from sympathetic inputs acts on $\alpha$-cell and $\beta$-cell adrenergic receptors to raise glucagon, suppress insulin release, and ultimately elevate blood glu$\operatorname{cose}^{25,61}$. Sympathetic nervous innervation was therefore long considered to be the key source of NE acting on the endocrine pancreas ${ }^{25,26}$. However, there is increasing awareness that the precise extent of islet innervation is highly variable and species-dependent ${ }^{26-29,31}$. Compared to rodents, recent studies suggest much sparser innervation of human islets ${ }^{27,30}$. Furthermore, most sympathetic axons innervating the pancreas are associated with the smooth muscle cells of local blood vessels rather than local islet cells ${ }^{26,27,30,62}$. Islets also lack direct dopaminergic innervation in either humans or rodents ${ }^{27,33}$. Together, these studies suggest that autonomic sympathetic innervation cannot be the sole source of pancreatic catecholamines. Rather, growing evidence suggests that de novo local production of NE and DA by islet cells is a key source of catecholamines in the endocrine pancreas.

We and others previously showed that rodent and human $\beta$-cells express the machinery for DA biosynthesis including TH and AADC and produce DA independently of autonomic inputs ${ }^{6,7,9,63}$. Here, we demonstrate for the first time that human and mouse $\alpha$-cells also express the catecholamine biosynthetic machinery as well as the LAT1 and LAT2 transporters which are instrumental in cellular L-DOPA uptake ${ }^{7,64-66}$. Functionally, we show that $\alpha$-cells produce both L-DOPA and DA de novo and significantly boost DA production in response to exogenous L-DOPA supplementation. In contrast, both in vitro and 
in vivo studies suggest that $\beta$-cells synthesize little LDOPA de novo but instead rely on uptake of precursors from the peripheral circulation to drive DA production $^{6,7,9,33,34,59}$. Remarkably, after meals, blood L-DOPA and DA levels increase $>50$-fold in humans and rodents $^{67-71}$, allowing $\beta$-cells to tune DA synthesis and signaling to meal size ${ }^{7}$. Nevertheless, because $\alpha$-cells and $\beta$-cells exist in close proximity within islets ${ }^{72,73}$, we speculate that $\alpha$-cells can directly supply their de novosynthesized L-DOPA and DA to nearby $\beta$-cells. Indeed, our data showing that human $\beta$-cells express DAT may also be consistent with such a possibility, enabling rapid $\beta$-cell uptake of locally-produced islet DA. Moreover, the expression of DAT in $\alpha$-cells could provide an additional layer of control over local DA signaling by facilitating rapid $\alpha$-cell DA reuptake to more effectively control exposure to islet DA. Ultimately, our proposed paracrine mechanism would enable rapid, dynamic coordination of intra-islet DA signaling to further fine-tune regulation of insulin and glucagon secretion. Future experiments are needed to test these possibilities.

We also show that mouse $\alpha$-cells produce NE both de novo and in response to L-DOPA treatment since LDOPA is a precursor for NE as well as for $\mathrm{DA}^{36,71}$. Yet, while L-DOPA uptake substantially boosts $\alpha$-cell DA production (60-fold), there is considerably less enhancement in NE production (3-fold). This suggests that $\alpha$-cells preferentially produce DA over NE despite expressing $\mathrm{DBH}$, the enzyme responsible for converting DA to NE. We similarly did not find evidence of significant NE production in $\beta$-cells in our earlier studies ${ }^{7}$. Yet, despite the preference for DA production, $\alpha$-cells and $\beta$-cells still express adrenergic receptors, and for some receptor subtypes, to a significantly greater degree relative to D2R/ D3R. These data suggest a mismatch between the DA and NE produced by $\alpha$ - and $\beta$-cells and the catecholamine
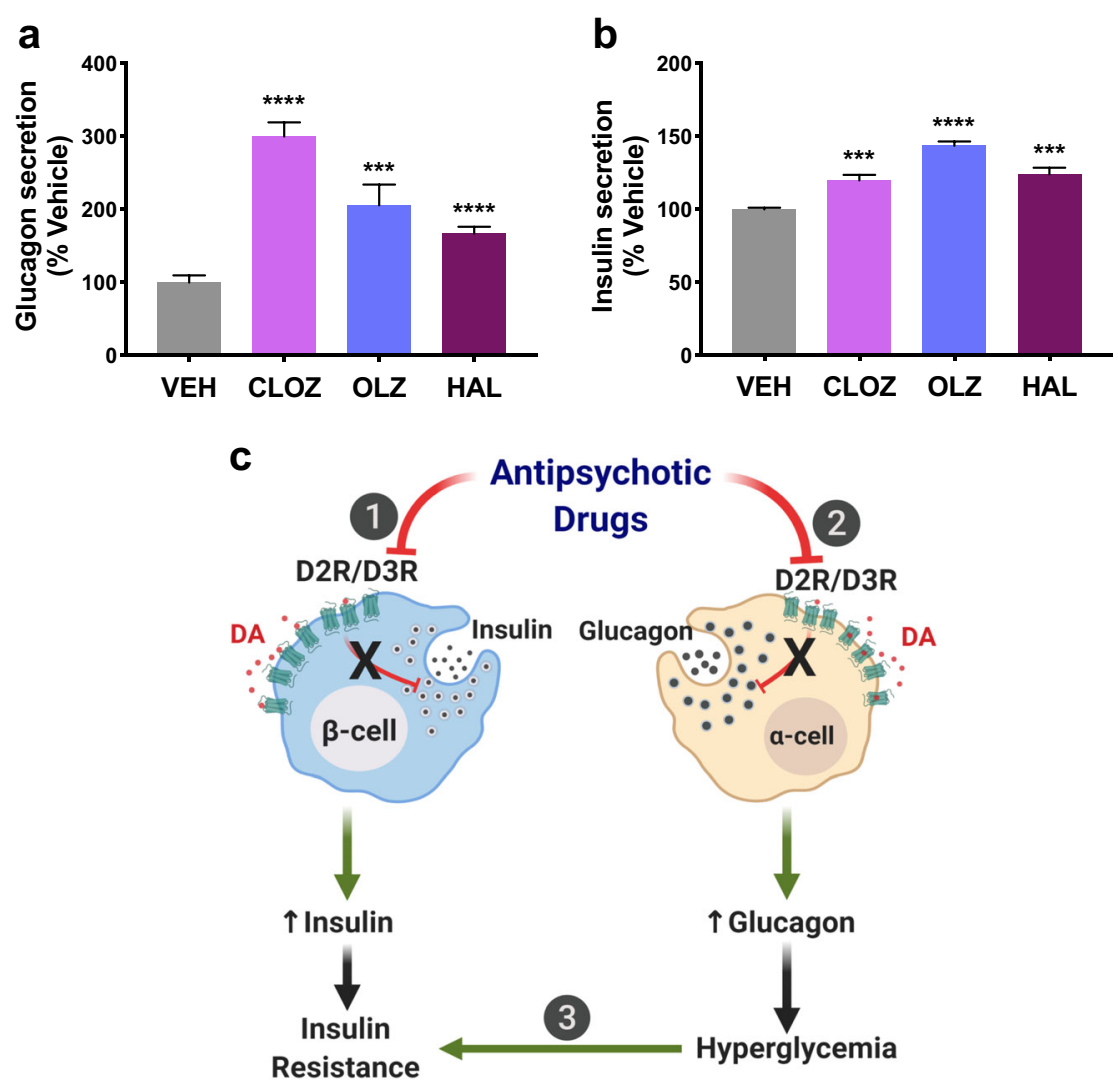

Fig. 4 Antipsychotic drugs increase pancreatic insulin and glucagon secretion in human islets. a Antipsychotic drugs (APDs) clozapine (CLZ), olanzapine (OLZ), and haloperidol (HAL) (all $1 \mu \mathrm{M})$ significantly raised a-cell glucagon secretion in isolated human islets (CLZ: $P<0.0001$; OLZ: $P=$ 0.0002; HAL: $P<0.0001$ ); and $\mathbf{b}$ raised glucose-stimulated insulin secretion from $\beta$-cells relative to vehicle controls, in the same human islets (CLZ: $P=$ 0.0006; OLZ: $P<0.0001 ; \mathrm{HAL}: P=0.0004)$. Results are normalized to the vehicle. Data are represented as means \pm SEM; two-tailed Student's $t$-test (a, b). ${ }^{* *} P<0.001,{ }^{* * * *} P<0.0001$. c Schematic summarizing APDs' actions on islet $\alpha$ - and $\beta$-cells. (1) In $\beta$-cells, APDs block inhibitory D2R/D3R, which ordinarily inhibit insulin release in response to DA stimulation. APDs thus disinhibit insulin release, leading to increased secreted insulin. Over time, this desensitizes insulin-sensitive organs to promote insulin resistance. (2) In parallel, APDs act directly on a-cells, disrupting inhibitory D2R/D3R signaling and elevating glucagon release. (3) The resulting increases in secreted glucagon produce hyperglycemia, which further exacerbates insulin resistance, and leads to an overall worsening of APD-induced dysglycemia. 
receptors expressed by the same cells. Similar mismatches have been described in the brain including regions of the dorsal striatum and prefrontal cortex which express high densities of $\alpha_{2}$-adrenergic receptors despite a paucity of noradrenergic nerve terminals and low levels of extracellular NE; rather, these regions exhibit dense dopaminergic innervation ${ }^{46,74-76}$. It has been postulated that DA serves as the endogenous substrate for these adrenergic receptors ${ }^{46,77}$. Several lines of evidence support this conclusion: (1) In vitro studies demonstrated that DA both binds and signals via $\alpha_{2}$-adrenergic receptors, albeit at lower affinities than $\mathrm{NE}^{46,78-80}$. (2) DA has been shown to signal via immune cell and cardiac $\beta$-adrenergic receptors $^{81,82}$. (3) Computational modeling studies demonstrate strong structural homologies between DA's interactions at binding sites of adrenergic receptors and $\mathrm{D}_{2}$-like receptors ${ }^{46,83}$.

Our radioligand binding data provides further support for DA's ability to signal via adrenergic receptors. We demonstrate that DA binds to endogenous $\beta$-cell $\alpha_{2 A^{-}}$ adrenergic receptors in the same range previously reported in mammalian brain ${ }^{46,84}$. Moreover, DA's actions at $\beta$-cell $\alpha_{2 \mathrm{~A}}$-adrenergic receptors are functionally relevant. CRISPR-Cas9 deletion of $\beta$-cell $\alpha_{2 \mathrm{~A}}$-adrenergic receptor in INS-1E cells reduces DA's ability to inhibit GSIS in the KO cells. Nevertheless, despite the loss of $\alpha_{2 \mathrm{~A}}$-adrenergic receptor expression, treatment with DA still causes smaller, though appreciable, dose-dependent inhibition of GSIS, and with higher potency. This suggests that the residual inhibition produced by DA in the $\alpha_{2 \mathrm{~A}}$-adrenergic receptor $\mathrm{KO}$ background unmasks the relative contributions of the inhibitory $\mathrm{G \alpha}_{\mathrm{i}}$-coupled $\beta$-cell DA $\mathrm{D}_{2}$-like receptors that remain expressed.

Our nanoBRET findings demonstrate that DA activation of the $\alpha_{2 \mathrm{~A}}$-adrenergic receptor primarily results in recruitment of $\mathrm{G \alpha}_{\mathrm{i} 1}$ to the receptor with negligible $\beta$-arrestin2 recruitment while NE treatment causes robust recruitment of both the $G$ protein and $\beta$-arrestin2. These data suggest for the first time that DA functions as a biased ligand when it signals specifically via the $\alpha_{2 A^{-}}$ adrenergic receptor. Such results are consistent with growing evidence that alternate ligands for GPCRs exhibit biased agonism. Indeed, alternate ligands for the galanin receptor (e.g., spexin) exhibit biased agonism toward G protein signaling compared to galanin ${ }^{85}$. Similar findings have been demonstrated by agouti-related peptide through melanocortin-3 and -4 receptors (MCR3, MCR4) or by endogenous opioid peptides at $\mathrm{k}$ - and $\mu$-opioid receptors $^{86-88}$. Importantly, DA's signaling bias provides an additional rationale for $\alpha$-cell and $\beta$-cell catecholamine receptor preferences for signaling via DA or NE. Since $\beta$-arrestin2 recruitment is important for GPCR desensitization and internalization ${ }^{89}$, we propose that DA's inability to effectively recruit $\beta$-arrestin2 to activated $\alpha_{2 A^{-}}$ adrenergic receptors may limit receptor desensitization. This can lead to sustained receptor signaling at the cell surface. We, therefore, speculate that these signaling differences between DA and NE may provide islet cells with an additional mechanism for finer temporal control of hormone release that may be especially critical for differential metabolic adaptations to states of acute and chronic stress when concentrations of circulating catecholamines are altered.

On the basis of our receptor binding and signaling data, we offer a model of dopaminergic hormone regulation in human islets (Fig. 5). Adequate expression of D2R and D3R in human $\alpha$-cells enables the high-affinity binding of DA even at low concentrations, leading to inhibitory $\mathrm{G \alpha}_{\mathrm{i}}$ signaling that diminishes glucagon release. At higher DA concentrations, there is sufficient DA to occupy $\beta$-adrenergic receptors. These $\alpha$-cell adrenergic receptors effectively function as lower-affinity DA targets, and their activation results in receptor recruitment of stimulatory $\mathrm{G \alpha}_{\mathrm{s}}$ that results in enhanced glucagon release. Consequently, the combined actions of DA at $\alpha$-cell adrenergic and dopaminergic receptors produces a biphasic glucagon response (Fig. 5a). By contrast, in human $\beta$-cells, low DA concentrations primarily direct signaling through the high-affinity D2R/D3R to inhibit insulin secretion. However, at higher DA concentrations, DA activates the lower-affinity $\alpha_{2 \mathrm{~A}}$-adrenergic receptors. Because both $\beta$-cell $D_{2}$-like and $\alpha_{2 \mathrm{~A}}$-adrenergic receptors are coupled to inhibitory $G \alpha_{i}$, activation of either receptor type still inhibits insulin secretion (Fig. 5b). In such a model, DA's ability to selectively signal via high- and low-affinity receptor populations enables $\alpha$-cells and $\beta$-cells to coordinate with one another to finely tune hormone release according to local DA availability.

In addition to $\alpha$-cells and $\beta$-cells, there is increasing evidence suggesting that other pancreatic islet cell types also express $\mathrm{D}_{2}$-like receptors. In particular, both human and rodent somatostatin (SST)-secreting $\delta$-cells abundantly express $D 2 R^{22,90,91}$. Earlier work in rat islets showed that DA inhibits SST secretion via its actions on $\mathrm{D}_{2}$-like receptors ${ }^{92}$. This raises the possibility that the DA synthesized by $\alpha$ - and $\beta$-cells also locally activates $\delta$-cell D2R to inhibit SST secretion and thus removes SSTmediated inhibition of insulin and glucagon release $^{32,91,93-98}$. Such paracrine DA signaling that involves $\alpha-, \beta-$, and $\delta$-cells may offer an additional dimension to our understanding of the intra-islet regulation of hormone secretion. Future studies will further explore such paracrine DA crosstalk between $\alpha$-, $\beta$-, and $\delta$-cells.

Lastly, we demonstrate that APDs clozapine, olanzapine, and haloperidol all significantly elevate secretion of glucagon in human islets. Our findings validate earlier work showing that APD blockade of $\beta$-cell D2R/D3R 


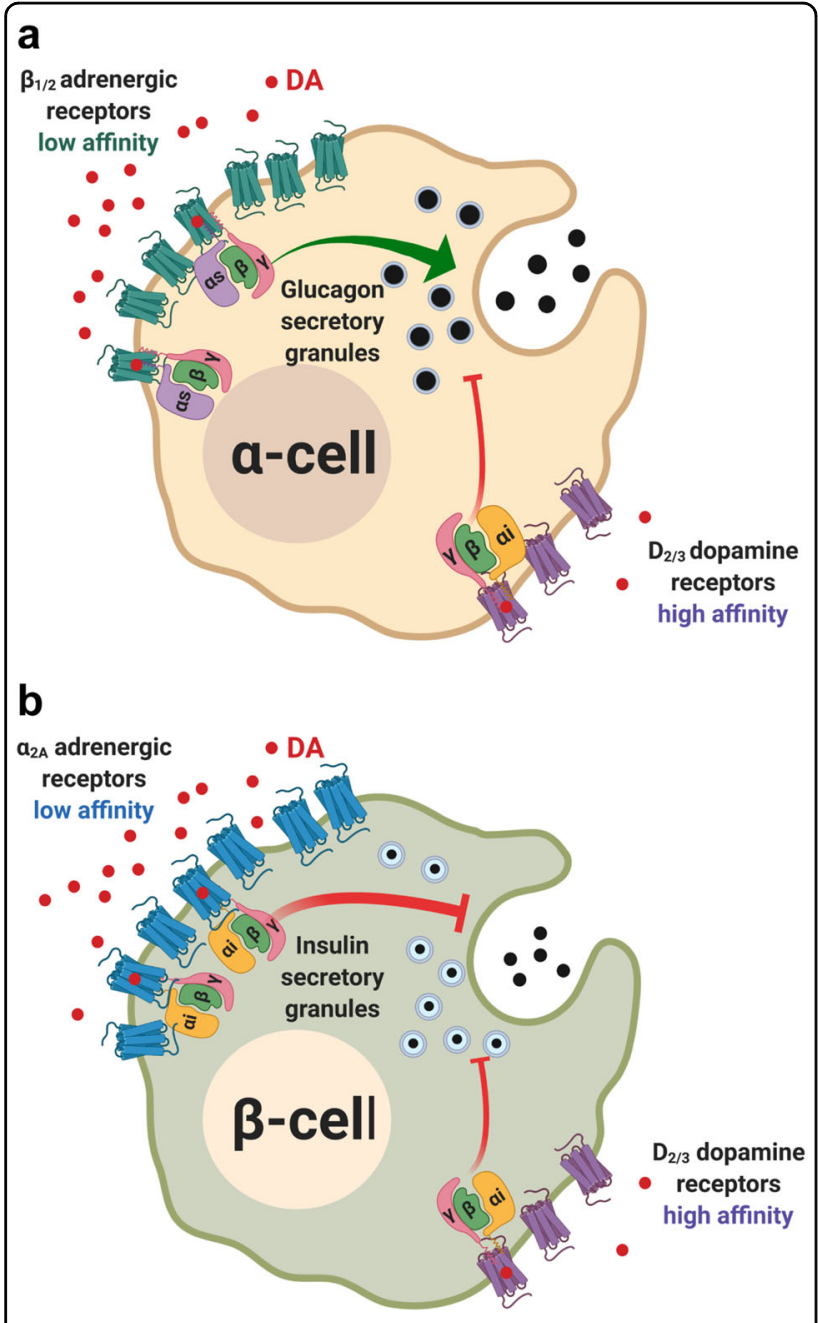

Fig. 5 Model for dopamine-mediated regulation of pancreatic aand $\beta$-cell hormone secretion. a In a-cells, low concentrations of local dopamine (DA) are sufficient to stimulate high-affinity $D_{2}$-like receptors to diminish glucagon secretion via inhibitory $\mathrm{Ga}_{\mathrm{i}}$-mediated intracellular signaling. At higher concentrations, there is sufficient DA to trigger the activation of stimulatory $\beta$-adrenergic receptors. This results in increased glucagon secretion via stimulatory $\mathrm{Ga}_{\mathrm{s}}$-mediated signaling. $\mathbf{b}$ In $\beta$-cells, at low DA concentrations, DA primarily signals through the high-affinity $D_{2}$-like receptors to inhibit insulin secretion. At higher DA concentrations, the lower-affinity $a_{2 A}$-adrenergic receptors are also activated to maintain overall inhibition of insulin release since both high- and low-affinity catecholamine receptors are coupled to inhibitory $\mathrm{Ga}_{\mathrm{i}}$.

elevates insulin secretion from rodent and human islets ${ }^{6,7}$. Just as importantly, we now find that APDs act directly on an additional target in the periphery, pancreatic $\alpha$-cells, where $\mathrm{D} 2 \mathrm{R} / \mathrm{D} 3 \mathrm{R}$ antagonism by these drugs increases glucagon release. Our results provide further evidence of a D2R/D3R-dependent inhibitory mechanism that regulates $\alpha$-cell hormone secretion, and that disruption of this signaling by APDs increases glucagon release. Indeed, inappropriately elevated blood glucagon levels are a characteristic feature of APD treatment in humans and rodents in vivo ${ }^{16,19-21}$. These APD-induced increases in glucagon occur despite concurrent increases in blood insulin and glucose - conditions that ordinarily decrease glucagon $^{19,21}$. APD-elevated glucagon may therefore drive the hyperglycemic states that these drugs produce since glucagon receptor $\mathrm{KO}$ mice are protected against $\mathrm{APD}$ induced hyperglycemia independently of changes in insulin levels ${ }^{21}$. Notably, the APD-dependent increases in human islet glucagon secretion observed here also correlate with the relative metabolic liabilities of these APDs with clozapine $>$ olanzapine $>$ haloperidol $^{3,4}$. Such findings further suggest an important role for drug-induced derangements of $\alpha$-cell function in producing clinically relevant metabolic disturbances.

Limitations of our work include the possibility that catecholamine signaling in $\alpha$-cells in vivo differs from the signaling we observed either in ex vivo human or mouse islet preparations or in vitro in tissue culture experiments. Moreover, since we used human islets from cadaveric donor pancreata, there could be potential confounding factors including postmortem interval and cause of death that may impact islet function. Additionally, aside from the APDs used in our present studies, the impacts of APDs including partial $\mathrm{D}_{2}$-like receptor agonists (e.g., aripiprazole, brexpiprazole $)^{99,100}$ and other secondgeneration antipsychotics with a lower risk for weight gain (e.g., ziprasidone) ${ }^{101}$ on $\alpha$ - and $\beta$-cell DA signaling have yet to be studied. Future work will therefore examine these outstanding issues.

In summary, the results presented here establish DA as a modulator of glucagon and insulin secretion via its actions on both adrenergic and dopaminergic receptors in human and mouse islets. Furthermore, we show that pancreatic $\alpha$-cells produce DA de novo and secrete it. The resulting dopaminergic modulation of pancreatic hormone secretion is dependent upon both cell type- and species-specific differences in expression levels of dopaminergic and adrenergic receptors. Overall, our work demonstrates a key signaling interplay between DA and $\mathrm{NE}$ in $\alpha$ - and $\beta$-cells as a novel regulatory pathway for pancreatic hormone release and offers the promise of new therapeutic approaches to treat the dysfunctional secretion of insulin and glucagon by targeting peripheral catecholamine receptors.

\section{Acknowledgements}

We thank Drs. George Gittes, Yi Sheng, Andrea Workman, Kyle Orwig, Nicholas Pierre, and Julie Valleghe. These studies were supported by the Department of Defense (PR141292) (Z.F., D.A.), the John F. and Nancy A. Emmerling Fund of The Pittsburgh Foundation (Z.F.), NIH R21AG068607 (Z.F.), the Intramural Research Program of the National Institute of Neurological Disorders and Stroke (NINDS) in the National Institutes of Health (NIH) (M.S.-S., R.B.F., D.R.S.), Veterans Affairs VA-ORD-BLR\&D I01BX002678 (V.K.Y.), and NIH R01DK097160 (V. K.Y.). Schematic figures were created with BioRender.com. 


\section{Author details}

${ }^{1}$ Translational Neuroscience Program, Department of Psychiatry, University of Pittsburgh, Pittsburgh, PA, USA. ${ }^{2}$ Institute of Cellular Therapeutics, Allegheny Health Network Research Institute, Allegheny Health Network, Pittsburgh, PA, USA. ${ }^{3}$ Molecular Neuropharmacology Section, National Institute of Neurological Disorders and Stroke, National Institutes of Health, Bethesda, MD, USA. ${ }^{4}$ Division of Endocrinology, Diabetes \& Metabolism, Department of Medicine, Diabetes and Beta Cell Biology Center, University of Pittsburgh, Pittsburgh, PA, USA. ${ }^{5}$ Department of Biostatistics, University of Pittsburgh, Pittsburgh, PA, USA. ${ }^{6}$ Division of Diabetes, Endocrinology, and Metabolism, Department of Medicine, Vanderbilt University Medical Center, Nashville, TN, USA. ${ }^{7}$ Center for Systems Neurogenetics of Addiction, The Jackson Laboratory, Bar Harbor, ME, USA. ${ }^{8}$ Department of Cell Physiology and Metabolism, University of Geneva, Geneva, Switzerland. ${ }^{9}$ Department of Biological Sciences, Carnegie Mellon University, Pittsburgh, PA, USA. ${ }^{10}$ College of Medicine, Drexel University, Philadelphia, PA, USA. " 1 Department of Cell Biology, University of Pittsburgh, Pittsburgh, PA, USA

\section{Author contributions}

The study was designed and conceptualized by Z.F. and D.A. Experiments were conducted by D.A., S.B., M.S.S., and J.L.; W.Z., X.X., S.S., M.B., and R.W.L. analyzed transcriptomic data. Experimental design and data interpretation were conducted by D.A., S.B., M.S.-S., R.B.F., J.L., C.B.W., M.T., V.K.Y., D.R.S., R.B., and Z.F. The manuscript was written by D.A. and Z.F with input from the other authors.

\section{Conflict of interest}

The authors declare that they have no conflict of interest.

\section{Publisher's note}

Springer Nature remains neutral with regard to jurisdictional claims in published maps and institutional affiliations.

Supplementary Information accompanies this paper at (https://doi.org/ 10.1038/s41398-020-01171-z).

Received: 30 June 2020 Revised: 13 October 2020 Accepted: 26 October 2020

Published online: 16 February 2021

\section{References}

1. Moore, T. J. \& Mattison, D. R. Adult utilization of psychiatric drugs and differences by sex, age, and race. JAMA Intern. Med. 177, 274-275 (2017).

2. Alexander, G. C., Gallagher, S. A., Mascola, A., Moloney, R. M. \& Stafford, R. S. Increasing off-label use of antipsychotic medications in the United States, 1995-2008. Pharmacoepidemiol. Drug Saf. 20, 177-184 (2011).

3. Ballon, J. S., Pajvani, U., Freyberg, Z., Leibel, R. L. \& Lieberman, J. A. Molecular pathophysiology of metabolic effects of antipsychotic medications. Trends Endocrinol. Metab. 25, 593-600 (2014).

4. Freyberg, Z., Aslanoglou, D., Shah, R. \& Ballon, J. S. Intrinsic and antipsychotic drug-induced metabolic dysfunction in schizophrenia. Front. Neurosci. 11, 432 (2017).

5. Rubi, B. et al. Dopamine $\mathrm{D}_{2}$-like receptors are expressed in pancreatic beta cells and mediate inhibition of insulin secretion. J. Biol. Chem. 280, 36824-36832 (2005).

6. Simpson, N. et al. Dopamine-mediated autocrine inhibitory circuit regulating human insulin secretion in vitro. Mol. Endocrinol. 26, 1757-1772 (2012).

7. Farino, Z. J. et al. New roles for dopamine $D_{2}$ and $D_{3}$ receptors in pancreatic beta cell insulin secretion. Mol. Psychiatry 25, 2070-2085 (2020).

8. Farino, Z. J. et al. Development of a rapid insulin assay by homogenous timeresolved fluorescence. PLOS ONE 11, e0148684 (2016).

9. Ustione, A. \& Piston, D. W. Dopamine synthesis and $D_{3}$ receptor activation in pancreatic $\beta$-cells regulates insulin secretion and intracellular $[\mathrm{Ca}(2+)]$ oscillations. Mol. Endocrinol. 26, 1928-1940 (2012).

10. Merglen, A. et al. Glucose sensitivity and metabolism-secretion coupling studied during two-year continuous culture in INS-1E insulinoma cells. Endocrinology 145, 667-678 (2004). 2004.
11. Garcia-Tornadu, I. et al. Disruption of the dopamine $D_{2}$ receptor impairs insulin secretion and causes glucose intolerance. Endocrinology 151, 1441-1450 (2010).

12. Rosati, G., Maioli, M., Aiello, I., Farris, A. \& Agnetti, V. Effects of long-term Ldopa therapy on carbohydrate metabolism in patients with Parkinson's disease. Eur. Neurol. 14, 229-239 (1976).

13. Ericson, L. E., Hakanson, R. \& Lundquist, I. Accumulation of dopamine in mouse pancreatic B-cells following injection of L-DOPA. Localization to secretory granules and inhibition of insulin secretion. Diabetologia 13, 117-124 (1977).

14. Zern, R. T., Bird, J. L. \& Feldman, J. M. Effect of increased pancreatic islet norepinephrine, dopamine and serotonin concentration on insulin secretion in the golden hamster. Diabetologia 18, 341-346 (1980).

15. Mehran, A. E. et al. Hyperinsulinemia drives diet-induced obesity independently of brain insulin production. Cell Metab. 16, 723-737 (2012).

16. Elias, A. N. \& Hofflich, H. Abnormalities in glucose metabolism in patients with schizophrenia treated with atypical antipsychotic medications. Am. J. Med. 121, 98-104 (2008).

17. Charron, M. J. \& Vuguin, P. M. Lack of glucagon receptor signaling and its implications beyond glucose homeostasis. J. Endocrinol. 224, R123-R130 (2015).

18. Knop, F. K. EJE PRIZE 2018: a gut feeling about glucagon. Eur. J. Endocrinol. 178, R267-R280 (2018).

19. Smith, G. C., Chaussade, C., Vickers, M., Jensen, J. \& Shepherd, P. R. Atypical antipsychotic drugs induce derangements in glucose homeostasis by acutely increasing glucagon secretion and hepatic glucose output in the rat. Diabetologia 51, 2309-2317 (2008).

20. Nagata, M., Kimura, Y., Ishiwata, Y., Takahashi, H. \& Yasuhara, M. Clozapineinduced acute hyperglycemia is accompanied with elevated serum concentrations of adrenaline and glucagon in rats. Biol. Pharm. Bull. 41, 1286-1290 (2018).

21. Castellani, L. N. et al. Glucagon receptor knockout mice are protected against acute olanzapine-induced hyperglycemia. Psychoneuroendocrinology $\mathbf{8 2}$, 38-45 (2017).

22. Chen, Y. et al. Distinctive expression and cellular distribution of dopamine receptors in the pancreatic islets of rats. Cell Tissue Res. 357, 597-606 (2014).

23. Zhang, $Y$. et al. Pancreatic endocrine effects of dopamine receptors in human islet cells. Pancreas 44, 925-929 (2015).

24. Sorenson, R. L., Elde, R. P. \& Seybold, V. Effect of norepinephrine on insulin, glucagon, and somatostatin secretion in isolated perifused rat islets. Diabetes 28, 899-904 (1979).

25. Thorens, B. Neural regulation of pancreatic islet cell mass and function. Diabetes Obes. Metab. 16, 87-95 (2014).

26. Rodriguez-Diaz, R. et al. Innervation patterns of autonomic axons in the human endocrine pancreas. Cell Metab. 14, 45-54 (2011).

27. Rodriguez-Diaz, R. \& Caicedo, A. Neural control of the endocrine pancreas. Best. Pr. Res Clin. Endocrinol. Metab. 28, 745-756 (2014).

28. Lorenzi, M. et al. Dopamine during alpha- or beta-adrenergic blockade in man. Hormonal, metabolic, and cardiovascular effects. J. Clin. Invest. 63, 310-317 (1979).

29. Lorenzi, M. et al. Differential effects of L-dopa and apomorphine on glucagon secretion in man: evidence against central dopaminergic stimulation of glucagon. J. Clin. Endocrinol. Metab. 45, 1154-1158 (1977).

30. Chaudhry, S., Bernardes, M., Harris, P. E. \& Maffei, A. Gastrointestinal dopamine as an anti-incretin and its possible role in bypass surgery as therapy for type 2 diabetes with associated obesity. Miner. Endocrinol. 41, 43-56 (2016).

31. Tang, S. C. et al. Human pancreatic neuro-insular network in health and fatty infiltration. Diabetologia 61, 168-181 (2018).

32. Gylfe, E. \& Tengholm, A. Neurotransmitter control of islet hormone pulsatility. Diabetes Obes. Metab. 16, 102-110 (2014).

33. Ustione, A., Piston, D. W. \& Harris, P. E. Minireview: dopaminergic regulation of insulin secretion from the pancreatic islet. Mol. Endocrinol. 27, 1198-1207 (2013).

34. Maffei, A., Segal, A. M., Alvarez-Perez, J. C., Garcia-Ocaña, A. \& Harris, P. E. Antiincretin, anti-proliferative action of dopamine on $\beta$-cells. Mol. Endocrinol. 29, 542-557 (2015).

35. Eisenhofer, G. et al. Substantial production of dopamine in the human gastrointestinal tract. J. Clin. Endocrinol. Metab. 82, 3864-3871 (1997).

36. Eisenhofer, G., Kopin, I. J. \& Goldstein, D. S. Catecholamine metabolism: a contemporary view with implications for physiology and medicine. Pharm. Rev. 56, 331-349 (2004). 
37. Iturriza, F. C. \& Thibault, J. Immunohistochemical investigation of tyrosinehydroxylase in the islets of Langerhans of adult mice, rats and guinea pigs. Neuroendocrinology 57, 476-480 (1993).

38. Persson-Sjogren, S., Forsgren, S. \& Taljedal, I. B. Tyrosine hydroxylase in mouse pancreatic islet cells, in situ and after syngeneic transplantation to kidney. Histol. Histopathol. 17, 113-121 (2002).

39. Takayanagi, M. \& Watanabe, T. Immunocytochemical colocalizations of insulin, aromatic L-amino acid decarboxylase, dopamine beta-hydroxylase, S100 protein and chromogranin A in B-cells of the chicken endocrine pancreas. Tissue Cell 28, 17-24 (1996).

40. Newcomer, J. W. et al. Abnormalities in glucose regulation during antipsychotic treatment of schizophrenia. Arch. Gen. Psych. 59, 337-345 (2002).

41. Teff, K. L. et al. Antipsychotic-induced insulin resistance and postprandial hormonal dysregulation independent of weight gain or psychiatric disease. Diabetes 62, 3232-3240 (2013).

42. Aslanoglou, D., George, E. W. \& Freyberg, Z. Homogeneous time-resolved Forster resonance energy transfer-based assay for detection of insulin secretion. J. Vis. Exp. 135, 57531 (2018).

43. Bertera, S., Balamurugan, A. N., Bottino, R., He, J. \& Trucco, M. Increased yield and improved transplantation outcome of mouse islets with bovine serum albumin. J. Transpl. 2012, 856386 (2012)

44. Balamurugan, A. N., Chang, Y., Fung, J. J., Trucco, M. \& Bottino, R. Flexible management of enzymatic digestion improves human islet isolation outcome from sub-optimal donor pancreata. Am. J. Transpl. 3, 1135-1142 (2003).

45. Hughes, J. W., Ustione, A., Lavagnino, Z. \& Piston, D. W. Regulation of islet glucagon secretion: Beyond calcium. Diabetes Obes. Metab. 20, 127-136 (2018).

46. Sánchez-Soto, $M$. et al. $a_{2 A^{-}}$and $a_{2 C^{-}}$adrenoceptors as potential targets for dopamine and dopamine receptor ligands. Mol. Neurobiol. 55, 8438-8454 (2018).

47. Cheng, Y. \& Prusoff, W. H. Relationship between the inhibition constant (K1) and the concentration of inhibitor which causes 50 per cent inhibition $\left(I_{50}\right)$ of an enzymatic reaction. Biochem. Pharm. 22, 3099-3108 (1973).

48. Brissova, $M$. et al. a cell function and gene expression are compromised in type 1 diabetes. Cell Rep. 22, 2667-2676 (2018).

49. Saunders, D. C. et al. Ectonucleoside triphosphate diphosphohydrolase-3 antibody targets adult human pancreatic beta cells for in vitro and in vivo analysis. Cell Metab. 29, 745-754.e744 (2019).

50. DiGruccio, M. R. et al. Comprehensive alpha, beta and delta cell transcriptomes reveal that ghrelin selectively activates delta cells and promotes somatostatin release from pancreatic islets. Mol. Metab. 5, 449-458 (2016).

51. Ritchie, M. E. et al. Limma powers differential expression analyses for RNAsequencing and microarray studies. Nucleic Acids Res. 43, e47 (2015).

52. Rouille, Y., Westermark, G., Martin, S. K. \& Steiner, D. F. Proglucagon is processed to glucagon by prohormone convertase PC2 in alpha TC1-6 cells. Proc. Natl Acad. Sci. USA 91, 3242-3246 (1994).

53. Iversen, J. Adrenergic receptors and the secretion of glucagon and insulin from the isolated, perfused canine pancreas. J. Clin. Invest. 52, 2102-2116 (1973)

54. Samols, E. \& Weir, G. C. Adrenergic modulation of pancreatic A, B, and D cells alpha-Adrenergic suppression and beta-adrenergic stimulation of somatostatin secretion, alpha-adrenergic stimulation of glucagon secretion in the perfused dog pancreas. J. Clin. Invest. 63, 230-238 (1979).

55. Peterhoff, M. et al. Inhibition of insulin secretion via distinct signaling pathways in alpha2-adrenoceptor knockout mice. Eur. J. Endocrinol. 149, 343-350 (2003)

56. Beaulieu, J. M., Espinoza, S. \& Gainetdinov, R. R. Dopamine receptors - IUPHAR Review 13. Br. J. Pharm. 172, 1-23 (2015).

57. Hahn, M. et al. Atypical antipsychotics and effects of muscarinic, serotonergic, dopaminergic and histaminergic receptor binding on insulin secretion in vivo: an animal model. Schizophr. Res. 131, 90-95 (2011).

58. Garcia-Tornadu, I. et al. New insights into the endocrine and metabolic roles of dopamine D2 receptors gained from the Drd2 mouse. Neuroendocrinology 92, 207-214 (2010)

59. Korner, J. et al. A role for foregut tyrosine metabolism in glucose tolerance. Mol. Metab. 23, 37-50 (2019).

60. Caicedo, A. Paracrine and autocrine interactions in the human islet: more than meets the eye. Semin. Cell Dev. Biol. 24, 11-21 (2013).

61. Begg, D. P. \& Woods, S. C. Interactions between the central nervous system and pancreatic islet secretions: a historical perspective. Adv. Physiol. Educ. 37 53-60 (2013).
62. Cabrera, O. et al. The unique cytoarchitecture of human pancreatic islets has implications for islet cell function. Proc. Natl Acad. Sci. USA 103, 2334-2339 (2006)

63. Mitok, K. A. et al. Islet proteomics reveals genetic variation in dopamine production resulting in altered insulin secretion. J. Biol. Chem. 293, 5860-5877 (2018).

64. Uchino, H. et al. Transport of amino acid-related compounds mediated by Ltype amino acid transporter 1 (LAT1): insights into the mechanisms of substrate recognition. Mol. Pharm. 61, 729-737 (2002).

65. Khunweeraphong, $\mathrm{N}$. et al. Establishment of stable cell lines with high expression of heterodimers of human 4F2hc and human amino acid transporter LAT1 or LAT2 and delineation of their differential interaction with alpha-alkyl moieties. J. Pharm. Sci. 119, 368-380 (2012).

66. Camargo, S. M. et al. The molecular mechanism of intestinal levodopa absorption and its possible implications for the treatment of Parkinson's disease. J. Pharm. Exp. Ther. 351, 114-123 (2014).

67. Goldstein, D. S. et al. Sources and physiological significance of plasma dopamine sulfate. J. Clin. Endocrinol. Metab. 84, 2523-2531 (1999).

68. Eldrup, E., Moller, S. E., Andreasen, J. \& Christensen, N. J. Effects of ordinary meals on plasma concentrations of 3,4-dihydroxyphenylalanine, dopamine sulphate and 3,4-dihydroxyphenylacetic acid. Clin. Sci. 92, 423-430 (1997).

69. Eldrup, E. \& Richter, E. A. DOPA, dopamine, and DOPAC concentrations in the rat gastrointestinal tract decrease during fasting. Am. J. Physiol. Endocrinol. Metab. 279, E815-E822 (2000).

70. Eldrup, E., Richter, E. A. \& Christensen, N. J. DOPA, norepinephrine, and dopamine in rat tissues: no effect of sympathectomy on muscle DOPA. Am. J. Physiol. 256, E284-E287 (1989).

71. Goldstein, D. S., Eisenhofer, G. \& Kopin, I. J. Sources and significance of plasma levels of catechols and their metabolites in humans. J. Pharm. Exp. Ther. $\mathbf{3 0 5}$ 800-811 (2003). 2003.

72. Gylfe, E. \& Gilon, P. Glucose regulation of glucagon secretion. Diabetes Res. Clin. Pr. 103, 1-10 (2014)

73. Unger, R. H. \& Orci, L. Paracrinology of islets and the paracrinopathy of diabetes. Proc. Natl Acad. Sci. USA 107, 16009-16012 (2010).

74. Lindvall, O. \& Bjorklund, A. The organization of the ascending catecholamine neuron systems in the rat brain as revealed by the glyoxylic acid fluorescence method. Acta Physiol. Scand. Suppl. 412, 1-48 (1974).

75. Swanson, L. W. \& Hartman, B. K. The central adrenergic system. An immunofluorescence study of the location of cell bodies and their efferent connections in the rat utilizing dopamine-beta-hydroxylase as a marker. J. Comp. Neurol. 163, 467-505 (1975).

76. Goldman-Rakic, P. S., Lidow, M. S., Smiley, J. F. \& Williams, M. S. The anatomy of dopamine in monkey and human prefrontal cortex. J. Neural Transm. Suppl. 36, 163-177 (1992).

77. Zhang, W., Klimek, V., Farley, J. T., Zhu, M. Y. \& Ordway, G. A. alpha2C adrenoceptors inhibit adenylyl cyclase in mouse striatum: potential activation by dopamine. J. Pharm. Exp. Ther. 289, 1286-1292 (1999).

78. Alachkar, A., Brotchie, J. M. \& Jones, O. T. Binding of dopamine and 3methoxytyramine as I-DOPA metabolites to human alpha(2)-adrenergic and dopaminergic receptors. Neurosci. Res 67, 245-249 (2010).

79. Cornil, C. A. \& Ball, G. F. Interplay among catecholamine systems: dopamine binds to alpha2-adrenergic receptors in birds and mammals. J. Comp. Neurol. 511, 610-627 (2008).

80. Cornil, C. A., Castelino, C. B. \& Ball, G. F. Dopamine binds to alpha(2)-adrenergic receptors in the song control system of zebra finches (Taeniopygia guttata). J. Chem. Neuroanat. 35, 202-215 (2008).

81. Parrado, A. C. et al. Differential response of dopamine mediated by betaadrenergic receptors in human keratinocytes and macrophages: potentia implication in wound healing. Neuroimmunomodulation 24, 282-291 (2017).

82. Habuchi, Y. et al. Dopamine stimulation of cardiac beta-adrenoceptors: the involvement of sympathetic amine transporters and the effect of SKF38393. Br. J. Pharm. 122, 1669-1678 (1997).

83. Weichert, D., Stanek, M., Hubner, H. \& Gmeiner, P. Structure-guided development of dual $\beta_{2}$ adrenergic/dopamine $D_{2}$ receptor agonists. Bioorg. Med. Chem. 24, 2641-2653 (2016).

84. Sánchez-Soto, $M$. et al. Evidence for noncanonical neurotransmitter activation: norepinephrine as a dopamine $\mathrm{D}_{2}$-like receptor agonist. Mol. Pharm. 89, 457-466 (2016).

85. Reyes-Alcaraz, A., Lee, Y. N., Yun, S., Hwang, J. I. \& Seong, J. Y. Conformational signatures in beta-arrestin2 reveal natural biased agonism at a G-proteincoupled receptor. Commun. Biol. 1, 128 (2018). 
86. Yang, Z. \& Tao, Y. X. Biased signaling initiated by agouti-related peptide through human melanocortin-3 and -4 receptors. Biochim. Biophys. Acta 1862, 1485-1494 (2016).

87. Thompson, G. L. et al. Biased agonism of endogenous opioid peptides at the mu-opioid receptor. Mol. Pharm. 88, 335-346 (2015).

88. Dunn, A. D., Reed, B., Erazo, J., Ben-Ezra, A. \& Kreek, M. J. Signaling properties of structurally diverse kappa opioid receptor ligands: toward in vitro models of in vivo responses. ACS Chem. Neurosci. 10, 3590-3600 (2019).

89. Peterson, Y. K. \& Luttrell, L. M. The diverse roles of arrestin scaffolds in G protein-coupled receptor signaling. Pharm. Rev. 69, 256-297 (2017).

90. Lawlor, N. et al. Single-cell transcriptomes identify human islet cell signatures and reveal cell-type-specific expression changes in type 2 diabetes. Genome Res. 27, 208-222 (2017)

91. Bucolo, C., Leggio, G. M., Drago, F. \& Salomone, S. Dopamine outside the brain: The eye, cardiovascular system and endocrine pancreas. Pharm. Ther. 203, 107392 (2019)

92. Gerich, J. E., Charles, M. A. \& Grodsky, G. M. Characterization of the effects of arginine and glucose on glucagon and insulin release from the perfused rat pancreas. J. Clin. Invest. 54, 833-841 (1974).

93. Briant, L., Salehi, A., Vergari, E., Zhang, Q. \& Rorsman, P. Glucagon secretion from pancreatic alpha-cells. Ups. J. Med Sci. 121, 113-119 (2016).
94. Gylfe, E. Glucose control of glucagon secretion-There's a brand-new gimmick every year'. Ups. J. Med Sci. 121, 120-132 (2016).

95. Wendt, A. \& Eliasson, L. Pancreatic a-cells - the unsung heroes in islet function. Semin. Cell Dev. Biol. 103, 41-50 (2020).

96. Hauge-Evans, A. C., Bowe, J., Franklin, Z. J., Hassan, Z. \& Jones, P. M. Inhibitory effect of somatostatin on insulin secretion is not mediated via the CNS. J. Endocrinol. 225, 19-26 (2015).

97. Strowski, M. Z., Parmar, R. M., Blake, A. D. \& Schaeffer, J. M. Somatostatin inhibits insulin and glucagon secretion via two receptors subtypes: an in vitro study of pancreatic islets from somatostatin receptor 2 knockout mice. Endocrinology 141, 111-117 (2000).

98. Vergari, E. et al. Somatostatin secretion by $\mathrm{Na}^{+}$-dependent $\mathrm{Ca}^{2+}$-induced $\mathrm{Ca}^{2+}$ release in pancreatic delta-cells. Nat. Metab. 2, 32-40 (2020).

99. Keks, N. et al. Comparative tolerability of dopamine D2/3 receptor partial agonists for schizophrenia. CNS Drugs 34, 473-507 (2020).

100. Hope, J., Castle, D. \& Keks, N. A. Brexpiprazole: a new leaf on the partial dopamine agonist branch. Australas. Psychiatry 26, 92-94 (2018).

101. Dayabandara, M. et al. Antipsychotic-associated weight gain: management strategies and impact on treatment adherence. Neuropsychiatr. Dis. Treat. 13, 2231-2241 (2017). 